Harmful Algae

June 2017, Volume 66 Pages 65-78

http://dx.doi.org/10.1016/j.hal.2017.05.001

http://archimer.ifremer.fr/doc/00386/49765/

(c) 2017 Elsevier B.V. All rights reserved.

\title{
Adding new pieces to the Azadinium (Dinophyceae) diversity and biogeography puzzle: Non-toxigenic Azadinium zhuanum sp. nov. from China, toxigenic A. poporum from the Mediterranean, and a non-toxigenic $A$. dalianense from the French Atlantic
}

\author{
Luo Zhaohe ${ }^{1}$, Krock Bernd ${ }^{2}$, Mertens Kenneth ${ }^{3}$, Nezan Elisabeth ${ }^{3}$, Chomerat Nicolas ${ }^{3}$, \\ Bilien Gwenael ${ }^{3}$, Tillmann Urban ${ }^{2,{ }^{*}}$, Gu Haifeng ${ }^{1,}$
}

${ }_{1}^{1}$ SOA, Inst Oceanog 3, Xiamen 361005, Peoples R China.

${ }^{2}$ Alfred Wegener Inst Polar \& Marine Res, Handelshafen 12, D-27570 Bremerhaven, Germany.

3 IFREMER, LER BO, Stn Biol Marine, PI Croix,BP40537, F-29185 Concarneau, France.

* Corresponding authors : Urban Tillmann, email address : urban.tillmann@awi.de ; Haifeng Gu, email address : guhaifeng@tio.org.cn

\begin{abstract}
:
The marine planktonic dinophyceaen genus Azadinium is a primary source of azaspiracids, but due to their small size its diversity may be underestimated and information on its biogeography is still limited. A new Azadinium species, A. zhuanum was obtained from the East China Sea and Yellow Sea of China by incubating surface sediments. Five strains were established by isolating single germinated cells and their morphology was examined with light microscopy and scanning electron microscopy. Azadinium zhuanum was characterized by a plate pattern of Po, cp, X, 4', 2a, 6", 6C, 5S, 6"', 2"'", by a distinct ventral pore at the junction of Po, the first and fourth apical plates, and a conspicuous antapical spine. Moreover, Azadinium poporum was obtained for the first time from the Mediterranean by incubating surface sediment collected from Diana Lagoon (Corsica) and a new strain of Azadinium dalianense was isolated from the French Atlantic. The morphology of both strains was examined. Small subunit ribosomal DNA (SSU rDNA), large subunit ribosomal DNA (LSU rDNA) and internal transcribed spacer (ITS) sequences were obtained from cultured strains. In addition, LSU sequences were obtained by single cell sequencing of two presumable $A$. poporum cells collected from the French Atlantic. Molecular phylogeny based on concatenated SSU, LSU and ITS sequences revealed that $A$. zhuanum was closest to $A$. polongum. French $A$. poporum from Corsica (Mediterranean) and from the Atlantic showed some genetic differences but were nested within one of the $A$. poporum ribotypes together with other European strains. Azadinium dalianense from France together with the type strain of the species from China comprised a well resolved clade now consisting of two ribotypes. Azaspiracid profiles were analyzed for the cultured Azadinium strains using LC-MS/MS and demonstrate that the Mediterranean A. poporum strain produced AZA-2 and AZA-2 phosphate with an amount of $0.44 \mathrm{fg} \mathrm{cell}^{-1}$. Azadinium zhuanum and $A$. dalianense did not produce detectable AZA. Results of the present study support the
\end{abstract}


view of a high diversity and wide distribution of species belonging to Azadinium. The first record of AZA2 producing $A$. poporum from the Mediterranean suggests that this species may be responsible for azaspiracid contaminations in shellfish from the Mediterranean Sea.

\section{Highlights}

- Azadinium zhuanum sp. nov. was described. Azadinium poporum was reported in the Mediterranean Sea firstly. Mediterranean Azadinium poporum produces AZA-2. A new ribotype of Azadinium dalianense was reported.

Keywords : Azadinium, Azaspiracid, AZA-2, AZA-2 phosphate, Biogeography, China, French Atlantic, Mediterranean Sea 


\section{Introduction}

The genus Azadinium Elbrächter \& Tillmann is characterized by a plate pattern of Po, cp, X, 3-4', 2-3a, 6", 6C, 5S, 6"', 2'"' (Tillmann et al., 2009; Luo et al., 2013). Azadinium is closely related with Amphidoma as supported by both morphology and molecular phylogeny, thus they were included in the family Amphidomataceae. To which order these genera belong remains to be determined, since their morphology has both characteristics of Peridiniales and Gonyaulacales (Tillmann et al., 2012a). Since the description of Azadinium spinosum Elbrächter \& Tillmann (Tillmann et al., 2009), as many as eight new species (A. obesum Tillmann \& Elbrächter, A. poporum Tillmann \& Elbrächter, A. polongum Tillmann, A. dexteroporum Percopo \& Zingone, A. dalianense Z. Luo, H. Gu, Tillmann, A. triniatum Tillmann \& Nézan, A. cuneatum Tillmann \& Nézan and A. concinnum Tillmann \& Nézan) have been described based on comprehensive study of both morphology and molecular phylogeny (Tillmann et al., 2010; Tillmann et al., 2011; Tillmann et al., 2012b; Luo et al., 2013; Percopo et al., 2013; Tillmann et al., 2014a). Azadinium luciferelloides Tillmann \& Akselman, however, was described based on morphology only (Tillmann and Akselman, 2016). In addition, Amphidoma caudata Halldal has been transferred to Azadinium based on both morphology and molecular phylogeny (Nézan et al., 2012). The most important morphological features to distinguish Azadinium species include the location of ventral pore, the number of apical and anterior intercalary plates, and the presence or absence of an antapical spine (Tillmann et al., 2014a). Motile cells of Azadinium are relatively small in length - their size ranges between 10 and $20 \mu \mathrm{m}$ except for $A$. 
caudatum. Such small cells are easily overlooked in routine monitoring, and identification and a thorough morphological description and a molecular characterisation of new species in this size range relies on availability of strains in culture. Therefore, the current known diversity of Azadinium species may be underestimated. To study the biogeography of known Azadinium species, molecular detection is promising, but specific probes have been designed for only a few species yet (Toebe et al., 2013) and they are not yet routinely used (Smith et al., 2015). So currently information about the biogeography of Azadinium is still limited and some Azadinium species have not yet been reported elsewhere except the type locality, e.g. A. concinnum (Tillmann et al., 2014a).

The most notable feature of Azadinium is that some of the species (e.g., A. spinosum) are able to produce azaspiracids (AZA) (Tillmann et al., 2009; Salas et al. 2011) and thus were responsible for cases of human intoxication via mussel consumption. Azadinium poporum was originally described as a non-toxigenic species (Tillmann et al., 2011), but later it turned out that the type strain in fact produces a novel AZA (Krock et al., 2012), and that new strains of $A$. poporum produce diverse AZA (Gu et al., 2013; Krock et al., 2014). Moreover, A. poporum comprises several genetically different ribotypes that are morphologically indistinguishable. The strains from Europe and New Zealand share identical sequences and belong to ribotype A (Luo et al., 2016; Tillmann et al., 2017), whereas those from east Asia, Argentina, Gulf of Mexico belong to ribotypes B or C (Gu et al., 2013; Luo et al., 2016; Tillmann et al., 2016). Even with a relatively high number of sequenced $A$. poporum strains 
compared to other Azadinium species, new isolates and sequences from other localities may represent and reveal additional ribotypes.

Azadinium dalianense was described from the Yellow Sea of China (Luo et al., 2013) and reported to be present in an Azadinium bloom sample from the Argentinean shelf (Tillmann and Akselman 2016). Although an antapical spine was rare in the type strain, the Argentine field specimens always had one (Tillmann and Akselman, 2016). Only the Chinese strain of $A$. dalianense has been tested for AZA production with a negative result (Luo et al., 2013); more strains are needed for confirmation.

Along the coast of China, Azadinium poporum was recorded from several locations whereas A. dalianense was only reported in the Yellow Sea. However, an extended distribution of these and other Azadinium species in Chinese waters can be expected after more extensive sampling. Likewise, Azadinium poporum was reported in the North Sea, but not yet in French Atlantic waters, where currently Azadinium caudatum is the only recorded species of Azadinium (Nézan et al., 2012).

In the Mediterranean Sea, the recorded Azadinium diversity is low as well. To date, only an unidentified Azadinium species was encountered in water samples collected in Fangar Bay (Catalan coast, NW Mediterranean) (Busch et al., 2016), and A. dexteroporum has been reported from the Gulf of Naples (Percopo et al., 2013), which has been shown to produce seven (six of which were new to science) different AZA (Rossi et al. 2017). Bacchiocchi et al. (2015) reported AZA-2 in mussels collected in the Adriatic Sea, suggesting other toxic Azadinium species to be present.

In our ongoing attempts to complement diversity and biogeography of 
Amphidomataceae, new strains and records of Azadinium from Chinese and French waters were established. Cultured strains were examined in detail for their morphology, and were grown in larger quantities and analyzed for the presence of AZA. In addition, small subunit ribosomal DNA (SSU rDNA), partial large subunit ribosomal DNA (LSU rDNA) and internal transcribed spacer (ITS) sequences were determined for the cultured strains along with single cell sequencing of LSU of two Azadinium cells from field samples from the French Atlantic.

\section{Material and methods}

\subsection{Sample collection and treatment}

Sediment samples were collected from the Yellow Sea and the East China Sea (China), and from Diana Lagoon (Corsica, France, Mediterranean) in 2015 and 2016 using a grab (Table 1). The top $2 \mathrm{~cm}$ were sliced off and stored in the dark at $4{ }^{\circ} \mathrm{C}$ until further treatment. Approximately $5 \mathrm{~g}$ of wet sediment was mixed with $20 \mathrm{~mL}$ of filtered seawater and stirred vigorously to dislodge detrital particles. The settled material was subsequently sieved through $120 \mu \mathrm{m}$ and $10 \mu \mathrm{m}$ filters. The $10-120 \mu \mathrm{m}$ fractions were incubated in a series of small containers with $\mathrm{f} / 2-\mathrm{Si}$ medium (Guillard and Ryther, 1962) at $20^{\circ} \mathrm{C}, 90 \mu \mathrm{mol}$ quanta $\cdot \mathrm{m}^{-2} \cdot \mathrm{s}^{-1}$ under a $12: 12 \mathrm{~h}$ light: dark cycle (hereafter called "standard culture conditions"). Azadinium cells are characterized by swimming at low speed, interrupted by short, high-speed 'jumps' in various directions (Tillmann et al., 2009). Cells exhibiting such a characteristic swimming behavior 
were isolated with a micropipette under an inverted microscope Eclipse TS100 (Nikon, Tokyo, Japan) and established in clonal cultures under standard culture conditions.

One strain of Azadinium dalianense was established by isolating a single cell from a plankton net sample collected in Concarneau Bay, France in 2013 (Table 1). Two cells of presumably Azadinium poporum were isolated from water samples collected in Brest Bay and Etel river inlet, Kerros, France in 2008 and 2010 for single cell sequencing (Table 1).

\subsection{Light microscopy (LM)}

Live cells were examined and photographed using a Zeiss Axio Imager microscope (Carl Zeiss, Göttingen, Germany) equipped with a Zeiss Axiocam HRc digital camera. Cell size of fifty cells was measured using Axiovision (4.8.2 version) software at $\times 1000$ magnification. To observe the shape and location of the nucleus, cells were stained with 1:100 000 Sybr Green (Sigma Aldrich, St. Louis, USA) for $1 \mathrm{~min}$, and photographed under the Zeiss fluorescence microscope with a Zeiss-38 filter set (excitation BP 470/40, beam splitter FT 495, emission BP 525/50).

\subsection{Scanning electron microscopy (SEM)}

For Azadinium zhuanum and A. poporum, mid-exponential batch cultures were concentrated by a Universal 320 R centrifuge (Hettich-Zentrifugen, Tuttlingen, Germany) at $850 \mathrm{~g}$ for $10 \mathrm{~min}$ at room temperature. The cell pellet was treated as 
described by Tillmann et al. (2009) to strip off the outer cell membrane. Cells were fixed with $2.5 \%$ glutaraldehyde for $3 \mathrm{~h}$ at $8{ }^{\circ} \mathrm{C}$, and post-fixed with $1 \% \mathrm{OsO}_{4}$ over night at $8{ }^{\circ} \mathrm{C}$ after twice washing with Milli-Q water. The supernatant was removed and the settled cells were transferred to a coverslip coated with poly-L-lysine (molecular weight 70,000-150,000). The attached cells were washed in Milli-Q water twice. The samples were then dehydrated in a series of ethanol $(10,30,50,70,90$ and $3 \times$ in 100\%, 10 min at each step), critical point dried (K850 Critical Point Dryer,

Quorum/Emitech, West Sussex, UK), sputter-coated with gold, and examined with a Zeiss Sigma FE (Carl Zeiss Inc., Oberkochen, Germany) scanning electron microscope.

For A. dalianense, cells from $1.5 \mathrm{~mL}$ of a dense culture were fixed as described by Tillmann et al. (2009), prepared according to the methods described in Nézan et al. (2014), and observed with a Quanta 200 (FEI, Eindhoven, Netherlands) scanning electron microscope.

\subsection{PCR amplifications and sequencing}

The total algal DNA of Azadinium zhuanum and Mediterranean A. poporum was extracted from $10 \mathrm{~mL}$ of exponentially growing cultures using a MiniBEST Universal DNA Extraction Kit (Takara, Tokyo, Japan) according to the manufacturer's protocol. PCR amplifications were carried out using $1 \times \mathrm{PCR}$ buffer, $50 \mu \mathrm{M}$ dNTP mixture, 0.2 $\mu \mathrm{M}$ of each primer, $10 \mathrm{ng}$ of template genomic DNA, and $1 \mathrm{U}$ of ExTaq DNA Polymerase (Takara, Tokyo, Japan) in $50 \mu$ L reactions. The SSU rDNA was amplified 
using the primers of PRIMER A/PRIMER B (Medlin et al., 1988). The LSU rDNA was amplified using the primers of D1R/28-1483R (Scholin et al., 1994; Daugbjerg et al., 2000). The total ITS1-5.8S-ITS2 was amplified using ITSA/ITSB primers (Adachi et al., 1996). The thermal cycle procedure was 4 min at $94^{\circ} \mathrm{C}$, followed by 30 cycles of $1 \mathrm{~min}$ at $94{ }^{\circ} \mathrm{C}, 1 \mathrm{~min}$ at $45^{\circ} \mathrm{C}, 1 \mathrm{~min}$ at $72^{\circ} \mathrm{C}$, and final extension of $7 \mathrm{~min}$ at $72{ }^{\circ} \mathrm{C}$ with a Mastercycler (Eppendorf, Hamburg, Germany). The PCR product was purified using a DNA purification kit (Shangong, Shanghai, China) and sequenced directly in both directions on an ABI PRISM 3730XL (Applied Biosystems, Foster City, CA, USA) following the manufacturer's instructions.

For Azadinium dalianense from the French Atlantic, the total algal DNA was extracted from $20 \mathrm{~mL}$ of an exponentially growing culture using the CTAB method (Doyle and Doyle, 1987). The molecular analysis was performed using the LSU rDNA and internal transcribed spacer (ITS). The first set of PCR primers was ITS-FW-D3B and the second set was D1R-D3B for 28S. ITS was amplified using the primers listed in Nézan et al. (2012). PCR was performed with $25 \mu \mathrm{L}$ reaction mixtures containing $12.5 \mu \mathrm{L}$ of $1 \mathrm{X}$ PCR master mix, $2.5 \mu \mathrm{L}$ of each primer and 6.5 $\mu \mathrm{L}$ of water. The amplification was realized in a TProfessional basic (Biometra, Göttingen, Germany) at $94^{\circ} \mathrm{C}$ for $2 \mathrm{~min}$, followed by 35 cycles of $94^{\circ} \mathrm{C}$ for $30 \mathrm{sec}$, $56^{\circ} \mathrm{C}$ for $1 \mathrm{~min}$ and $72^{\circ} \mathrm{C}$ for $4 \mathrm{~min}$ and a final extension at $72^{\circ} \mathrm{C}$ for $5 \mathrm{~min}$. PCR products were purified with a Wizard® SV Gel and PCR Clean-Up System Kit (Promega) according to the manufacturer's recommendations. Then, they were sequenced directly using the ABI PRISM BigDye Terminator Cycle Sequencing kit 
(Applied Biosystems, Carlsbad, USA). Sequencing products were purified by exclusion chromatography using the Dye Terminator Removal kit (Abgene Ltd., Epsom, UK) and the sequences were determined using an automated 3130 genetic analyzer (Applied Biosystems, Carlsbad, USA).

For Azadinium poporum from the French Atlantic, each cell was isolated from Lugol-fixed samples, using a micropipette under the Olympus IX70 inverted light microscope, and deposited on a glass slide. Then, it was placed in a drop of a sodium thiosulfate solution to decrease the inhibiting effect of the fixative on the PCR, and rinsed into two drops of double distilled water before transfer to a $0.2 \mathrm{~mL}$ PCR tube containing $3 \mu \mathrm{L}$ of water. PCR tubes were stored at $-20^{\circ} \mathrm{C}$ before the direct PCR amplification. A nested Polymerase chain reaction (PCR) was used for the amplification of LSU rDNA from A. poporum. The first set of PCR primers is D1R (Scholin et al., 1994) and 28-1483R (Daugbjerg et al., 2000) and the second set is D1R-LSUR2. Genomic DNA was amplified with the same protocol that is described above. Newly obtained sequences were deposited in the GenBank with accession numbers MF033109 to MF033126.

\subsection{Sequence alignment and phylogenetic analysis}

Newly obtained Azadinium sequences (nuclear-encoded SSU rRNA, partial LSU rRNA and ITS) were incorporated into those of Amphidomataceae and a systematically representative set of dinoflagellates available in GenBank based on studies by Tillmann et al. (2014a). Sequences were aligned using MAFFT v7.110 
(Katoh and Standley, 2013) online program (http://mafft.cbrc.jp/alignment/server/)

(Carroll et al., 2007). Alignments were manually checked with BioEdit v. 7.0.5 (Hall, 1999). For Bayesian inference (BI), the program jModelTest (Posada, 2008) was used to select the most appropriate model of molecular evolution with Akaike Information

Criterion (AIC). Bayesian reconstruction of the data matrix was performed using MrBayes 3.2 (Ronquist and Huelsenbeck, 2003) with the best-fitting substitution model (TIM1+G). Four Markov chain Monte Carlo (MCMC) chains ran for 2,000,000 generations, sampling every 100 generations. Convergence diagnostics were graphically estimated using AWTY (http://ceb.scs.fsu.edu/awty) (Nylander et al., 2008) and the first $10 \%$ of burn-in trees were discarded. A majority rule consensus tree was created in order to examine the posterior probabilities of each clade.

Maximum likelihood (ML) analyses were conducted with RaxML v7.2.6 (Stamatakis, 2006) on the T-REX web server (Boc et al., 2012) using the model GTR+G. Node support was assessed with 1000 bootstrap replicates.

\subsection{Chemical analysis of azaspiracids}

Cultures of A. zhuanum, A. poporum and A. dalianense were grown in $200 \mathrm{~mL}$ Erlenmeyer flasks under standard culture conditions to conduct an AZA analysis. About $10^{7}$ cells were collected by centrifugation at the exponential phase. Exponential phase was determined by harvesting $0.2 \mathrm{ml}$ culture every 3 days. Cells were enumerated using an inverted microscope and growth rate was calculated following the method of Stein (1973). Cell pellets were extracted with $300 \mu \mathrm{L}$ acetone by 
reciprocal shaking at $6.5 \mathrm{~m} \mathrm{~s}^{-1}$ with $0.9 \mathrm{~g}$ lysing matrix D (Thermo Savant, Illkirch, France) in a Bio101 FastPrep instrument (Thermo Savant, Illkirch, France) for $45 \mathrm{~s}$. The extracts were then centrifuged (Eppendorf 5415 R, Hamburg, Germany) at $16,100 \mathrm{~g}$ at $4{ }^{\circ} \mathrm{C}$ for $15 \mathrm{~min}$. Each supernatant was transferred to a $0.45-\mu \mathrm{m}$ pore-size spin-filter (Millipore Ultrafree, Eschborn, Germany) and centrifuged for $30 \mathrm{~s}$ at $800 \mathrm{~g}$, and the resulting filtrate was transferred into an LC autosampler vial for LC-MS/MS analysis.

\subsubsection{Single reaction monitoring (SRM) measurements}

Water was deionized and purified (Milli-Q, Millipore, Eschborn, Germany) to 18 $\mathrm{M} \Omega \mathrm{cm}^{-1}$ or better quality. Formic acid $(90 \%$, p.a.), acetic acid $(96 \%$, p.a.) and ammonium formate (98\%, p.a.) were from Merck (Darmstadt, Germany). The solvents, methanol and acetonitrile, were high performance liquid chromatography (HPLC) grade (Merck, Darmstadt, Germany).

Mass spectral experiments were performed to survey for a wide array of AZAs. The analytical system consisted of an AB-SCIEX-4000 Q Trap, triple quadrupole mass spectrometer equipped with a TurboSpray ${ }^{\circledR}$ interface coupled to an Agilent model 1100 LC. The LC equipment included a solvent reservoir, in-line degasser (G1379A), binary pump (G1311A), refrigerated autosampler (G1329A/G1330B), and temperature-controlled column oven (G1316A).

Separation of AZA ( $5 \mu \mathrm{L}$ sample injection volume) was performed by reverse-phase chromatography on a C8 phase. The analytical column $(50 \times 2 \mathrm{~mm})$ was packed with $3 \mu \mathrm{m}$ Hypersil BDS $120 \AA$ (Phenomenex, Aschaffenburg, Germany) 
and maintained at $20^{\circ} \mathrm{C}$. The flow rate was $0.2 \mathrm{~mL} \mathrm{~min}^{-1}$ and gradient elution was performed with two eluants, wherein eluant A was water and B was acetonitrile/water $(95: 5 \mathrm{v} / \mathrm{v})$, and both contained $2.0 \mathrm{mM}$ ammonium formate and $50 \mathrm{mM}$ formic acid. The initial conditions were 8 min column equilibration with $30 \% \mathrm{~B}$, followed by a linear gradient to $100 \% \mathrm{~B}$ in $8 \mathrm{~min}$, isocratic elution until 18 min with $100 \% \mathrm{~B}$, and then returning to the initial conditions until $21 \mathrm{~min}$ (total run time: $29 \mathrm{~min}$ ).

The AZA profiles were determined in one period $(0-18 \mathrm{~min})$ with curtain gas: 10 psi, CAD: medium, ion spray voltage: $5500 \mathrm{~V}$, ambient temperature; nebulizer gas at 10 psi, auxiliary gas was off, the interface heater was on, the declustering potential @ $100 \mathrm{~V}$, the entrance potential @ $10 \mathrm{~V}$, and the exit potential @ $30 \mathrm{~V}$. The SRM experiments were carried out in positive ion mode by selecting the transitions shown in Table 2. AZA were calibrated against an external standard solution of AZA-2 (certified reference material programme of the IMB-NRC, Halifax, Canada) and expressed as AZA-2 equivalents.

\subsubsection{Precursor ion experiments}

Precursors of the fragments $m / z, 348, m / z, 360$ and $m / z, 362$ were scanned in the positive ion mode from $\mathrm{m} / \mathrm{z} 400$ to 950 under the following conditions: curtain gas at $10 \mathrm{psi}, \mathrm{CAD}$ at medium, ion spray voltage at $5500 \mathrm{~V}$, ambient temperature, a $10 \mathrm{psi}$ nebulizer gas, the auxiliary gas was off, the interface heater was on, a declustering potential of $100 \mathrm{~V}$, a $10 \mathrm{~V}$ entrance potential, a $70 \mathrm{~V}$ collision energy, and a $12 \mathrm{~V}$ exit potential. 


\subsubsection{Collision Induced Dissociation (CID) spectra}

CID spectra of $\mathrm{m} / \mathrm{z} 856$ and $\mathrm{m} / \mathrm{z} 936$ were recorded in the Enhanced Product Ion mode in the mass range from $\mathrm{m} / \mathrm{z} 150$ to 960 in a positive ionization and unit resolution mode. The following parameters were applied: 10 psi curtain gas, medium $\mathrm{CAD}$, a $5500 \mathrm{~V}$ ion spray voltage, ambient temperature, a 10 psi nebulizer gas, the auxiliary gas was off, the interface heater was on, there was a $100 \mathrm{~V}$ declustering potential, the collision energy spread was 0 and $10 \mathrm{~V}$, and the collision energy was 70 V.

\section{Results}

\subsection{Morphology}

\subsubsection{Azadinium zhuanum sp. nov. Luo, Tillmann, Gu}

Diagnosis: Plate tabulation pattern Po, cp, X, 4', 2a, 6", 6C, 5S, 6"', 2"'"'. A ventral pore located at the right side of pore plate. Hypotheca with a conspicuous antapical spine. Vegetative cells $16.8-21.6 \mu \mathrm{m}$ long and $12.5-18.8 \mu \mathrm{m}$ wide.

Holotype: SEM stub TIO205-160419 from strain TIO205 deposited at Third Institute of Oceanography, SOA, Xiamen, 361005, China, illustrated in Figs 2, 3. Type locality: East China Sea $\left(27^{\circ} 28.04^{\prime} \mathrm{N}, 121^{\circ} 3.24^{\prime} \mathrm{E}\right)$.

Etymology: the specific epithet 'zhuanum' honors Professor Mingyuan Zhu, who carried out pioneering research on harmful algal blooms in China.

Distribution: East China Sea, Yellow Sea of China (Fig. S1).

The cells of strain TIO205 were 16.8-21.6 $\mu \mathrm{m}$ long (mean=18.5 $\pm 1.1 \mu \mathrm{m}, \mathrm{n}=50$ ) 
and 12.5-18.8 $\mu \mathrm{m}$ wide (mean=14.8 $\pm 1.4 \mu \mathrm{m}, \mathrm{n}=50$ ) with a median length: width ratio of 1.25 . The cells had a round epitheca and hypotheca, the latter ending with a conspicuous antapical spine (Fig. 1A and B). A single chloroplast was situated in the periphery of the cell ('c' in Fig. 1A). One presumable pyrenoid with a starch sheath visible was located either in the epitheca or hypotheca (Fig. 1A and B). A hyaline round structure, presumably representing a pusule, was visible in the equatorial part of the cell ('Pu' in Fig. 1A). The nucleus was large and slightly elongated and was located in the low part of the epitheca ('N' in Fig. 1B and C). Spherical cysts were frequently observed in cultures of strain TIO213 with a diameter of 14.0-15.2 $\mu \mathrm{m}$ (mean=14.7 $\pm 0.4 \mu \mathrm{m}, \mathrm{n}=10$ ) (Fig. 1D). The cyst had a brownish thin outer wall and a thick transparent endospore wall (Fig. 1D), and it included lipid bodies and lacked any ornamentation as observed with LM.

Under SEM, A. zhuanum showed a plate pattern of Po, cp, X, 4', 2a, 6", 6C, 5S, 6"', $2^{\prime \prime \prime \prime}$ (Fig. 2). The thin thecal plates had small pores with a diameter of $0.06-0.12 \mu \mathrm{m}$ (mean: $0.09 \mu \mathrm{m}, \mathrm{n}=100$ ) scattered on their surface except the small sulcal plates $\mathrm{Sm}$ and Sd (Figs 2,3). These pores were often distributed close to the plate margins, and the number per plate could reach as many as 20 . The number of pores on a specific plate could vary, e.g., the second apical plate could have between 3 and 7 pores (Fig. 3A and B).

The cingulum was deeply excavated and descended about half of its width, comprising of six plates of almost equal size (Fig. 2A and B, Fig. 3E, Fig. 4). There were four small apical plates and two anterior intercalary plates (1a and 2a) (Fig. 2B 
and C, Fig. 3B). Plates 1a and 2a were hexagonal, with 1a about 1.5 times larger than 2a in surface area (Fig. 2B and C). The plates $5^{\prime \prime}$ and $5^{\prime \prime \prime}$ were the largest within the precingular and postcingular series plates, respectively (Fig. 2C and D). The first antapical plate $\left(1^{\prime \prime \prime \prime}\right)$ was much smaller than the second antapical plate $\left(2^{\prime \prime \prime \prime}\right)$ and displaced to the left (Fig. 2D). A conspicuous antapical spine $0.81-1.51 \mu \mathrm{m}$ long (mean: $1.13 \mu \mathrm{m}, \mathrm{n}=14)$ was present on plate $2^{\prime \prime \prime \prime}$ of most observed cells $(95.4 \%, \mathrm{n}=91)$ (Fig. 2D, Fig. S2F).

A round apical pore was located in the centre of a pore plate $(\mathrm{Po})$ covered by a cover plate (cp) (Fig. 3A and B). There was a distinct ventral pore (vp) located at the junction of the pore plate, plates $1^{\prime}$ and $4^{\prime}$ (Fig. 3B). The ventral pore was located inside the pore plate and did not contact plate 1' (Fig. 3B). The cover plate was connected through a finger-like protrusion to the small canal plate (X) (Fig. 3B). Plate $1^{\prime}$ was symmetrical with the sutures to the precingular plates much longer than the sutures to the adjacent apical plates (Fig. 2A, Fig. 3A and B). The sulcus was composed of an anterior sulcal plate $(\mathrm{Sa})$, a median sulcal plate $(\mathrm{Sm})$, a right sulcal plate (Sd), a left sulcal plate (Ss), and a posterior sulcal plate (Sp) (Fig. 3C and D). There was a group of pores (typically around 10) located on the dorsal side of the second antapical plate (Fig. 3F). The typical plate pattern of A. zhuanum was illustrated in Fig. 4.

Plate variability was observed in the same culture, e.g., three or five instead of four apical plates $(5.9 \%$ and $7.8 \%$, respectively, $n=51)$ were observed (Fig. S2A and B). The presence of one or three anterior intercalary plates $(7.3 \%$ and $5.5 \%$, 
respectively, n=55) were also observed (Fig. S2C and D). The presence of one or three antapical plates $(7.1 \%$ and $3.6 \%$, respectively, $n=28)$ were also observed (Fig. S2E and F).

Growth bands were visible as faint striated rows showing the characteristic pattern of plate overlap (Fig. 2C and D). The plate overlap pattern was individually identified from both internal and external thecal views (Figs 2, 3). The plate overlap pattern of Azadinium zhuanum was characterized by two gradients, from dorsal to ventral and from cingulum to pole (Fig. 4C and D). Plates 3", C3 and 4"' overlapped all their neighboring plates, and thus were identified as the 'keystone plates'. In contrast, plates 1', 3' and Sp were overlapped by all adjacent apical, precingular, postcingular, and antapical plates.

\subsubsection{Azadinium poporum}

The cells of strain TIO256 from Corsica were 10.8-15.7 $\mu \mathrm{m}$ long (mean=13.5 \pm 1.4 $\mu \mathrm{m}, \mathrm{n}=50$ ) and $8.1-11.4 \mu \mathrm{m}$ wide (mean $=9.8 \pm 1.0 \mu \mathrm{m}, \mathrm{n}=50$ ) with a median length: width ratio of 1.38 .

Under SEM, A. poporum strain TIO256 showed a plate pattern of Po, cp, X, 4', 3a, 6", 6C, 5S, 6"', 2"'"' (Fig. 5). The cells had a conical epitheca and a hemispherical hypotheca (Fig. 5A and B). The cingulum was deeply excavated and descended less than half of its width (Fig. 5A and B). The sulcus was composed of five sulcal plates of Sa, Sm, Sd, Ss and Sp (Fig. 5C). A rounded apical pore was located in the centre of the pore plate $(\mathrm{Po})$ and was covered by a cover plate (Fig. 5D). There was a distinct 
ventral pore (vp) located at the junction of the pore plate and the first two apical plates $\left(1^{\prime}, 2^{\prime}\right)$ (Fig. 5D). There were three anterior intercalary plates (1a, 2a and 3a) on the dorsal part of the epitheca (Fig. 5B and E). Plates 1a and 3a were much larger than the four-sided 2a plate (Fig. 5B and E). The first antapical plate (1'"'') was much smaller than the second antapical plate $\left(2^{\prime \prime \prime \prime}\right)$ and displaced to the left (Fig. 5F). Typically there was a distinct group of pores (around 15) located on the dorsal side of the second antapical plate (Fig. 5G).

\subsubsection{Azadinium dalianense}

The cells of strain IFR-ADA-01C from Concarneau Bay were 11.2-13.6 $\mu \mathrm{m}$ long (mean=12.0 $\pm 0.8 \mu \mathrm{m}, \mathrm{n}=8)$ and 8.9-10.6 $\mu$ m wide (mean=9.7 $\pm 0.7 \mu \mathrm{m}, \mathrm{n}=9)$ with a median length: width ratio of 1.25. The cells showed a plate pattern of Po, cp, X, 3', 2a, 6", 6C, 5S, 6"', 2"'" (Fig. 6). The cells had a conical epitheca and a hemispherical hypotheca (Fig. 6A and B). The cingulum was deeply excavated and descended slightly less than half of its width (Fig. 6A and B). The apical pore was round, covered by a cover plate, and located in the centre of pore plate (Fig. 6C). The ventral pore was located at the junction of the plates Po, $1^{\prime}$ and $2^{\prime}$ (Fig. 6C). There were two anterior intercalary plates (1a and 2a) on the dorsal part of the epitheca (Fig. 6B and C). Plate 1a was pentagonal and slightly larger than the hexagonal plate 2 a (Fig. 6B and C). The plates 2 " and 4 " were distinctly smaller than other precingular plates (Fig. 6C). The sulcus comprised five sulcal plates of $\mathrm{Sa}, \mathrm{Sm}, \mathrm{Sd}, \mathrm{Ss}$ and $\mathrm{Sp}$ (Fig. 6A and D). The plate 2 '"' always had a short antapical spine and was much larger than the plate 
$1^{\prime \prime \prime \prime}$ (Fig. 6D). There was a distinct group of pores (typically around 14) located on the dorsal side of plate 2"'" (Fig. 6D).

\subsection{Molecular analysis and phylogeny}

Azadinium zhuanum strains shared nearly identical SSU, LSU and ITS sequences, and they shared $98.6 \%$ (SSU), $87.9 \%$ (LSU), and $78.3 \%$ (ITS) similarity with the $A$. polongum strain SHETB2, respectively.

For the LSU sequences, the similarity among the different ribotypes of Azadinium poporum ranged from $96.4 \%$ to $100.0 \%$ and the genetic distances ranged from 0.0 to 0.03. The similarity between the strains of Azadinium dalianense was $97.3 \%$ and the genetic distances was 0.02 (Table 3). For the ITS sequences, the similarity among the different ribotypes of $A$. poporum ranged from $96.3 \%$ to $98.3 \%$, and the genetic distances ranged from 0.02 to 0.03 . The similarity between Azadinium dalianense was 93.6\% and the genetic distances was 0.06 (Table 4).

The ML and BI analysis based on combined nuclear-encoded SSU rRNA, partial LSU rRNA gene and ITS sequences yielded similar phylogenetic trees. The BI tree was illustrated in Fig. 7 and S3. The Amphidomataceae were monophyletic with maximal support (bootstrap $=100 \%$ in $\mathrm{ML}$ and $\mathrm{pp}=1.00$ in $\mathrm{BI}$, respectively), and were a sister clade of Peridiniaceae/Thoracosphaeraceae (Fig. S3). Azadinium was monophyletic with strong support (bootstrap $=100 \%$ in ML and $\mathrm{pp}=0.98$ in BI, respectively), which formed a sister clade of Amphidoma with maximal support (Fig. 7). Azadinium zhuanum formed a sister clade of A. polongum with strong support 
(bootstrap $=100 \%$ in ML and $\mathrm{pp}=0.99$ in $\mathrm{BI}$, respectively). Azadinium dalianense strain IFR-ADA-01C from France and strain AZCH02 from China formed a well-resolved clade with maximal support, which was a sister clade of $A$. poporum with maximal support. The latter comprised three well-supported clades (referred as ribotypes A, B and C). Azadinium poporum from the Mediterranean Sea and French Atlantic were nested within ribotype A, together with North Sea strains of A. poporum from Denmark.

\subsection{AZA profile}

Precursor ion experiments of the typical AZA fragments $m / z 348, \mathrm{~m} / \mathrm{z} 360$ and $\mathrm{m} / \mathrm{z}$ 362 were performed with two Azadinium zhuanum strains, one strain of A. poporum and A. dalianense (Table 1). Whereas the $m / z, 348$ and the $m / z, 360$ experiments were negative, the $m / z 362$ experiment resulted in two peaks with $m / z, 856$ at a retention time of $12.4 \mathrm{~min}$ and $\mathrm{m} / \mathrm{z}, 936$ at $11.5 \mathrm{~min}$. These positive signals were obtained from A. poporum strain only. The CID spectra of both masses were recorded and resulted in identical spectra to those of AZA-2 and AZA-2 phosphate. Quantification of both compounds against an external calibration solution of AZA-2 in SRM mode gave an AZA-2 cell quota of $0.4 \mathrm{fg}^{\mathrm{c}} \mathrm{cll}^{-1}$. AZA-2 phosphate was expressed as AZA-2 equivalent and determined as $0.04 \mathrm{fg} \mathrm{cell}^{-1}$. The limit of detection (LOD) for AZA-2 in the SRM mode was determined as $0.007 \mathrm{fg}$ cell $^{-1}$. The LOD in the precursor mode experiments is approximately two orders of magnitude higher. 


\section{Discussion}

\subsection{Morphology and biogeography}

\subsubsection{Azadinium zhuanum}

Compared to all other species of Azadinium, A. zhuanum is unique by the presence of two anterior intercalary plates and four apical plates. Characteristically, a ventral pore in A. zhuanum is located at the right side of the pore plate. Such a pore, which is distinctly larger than normal thecal pores and is formed within a platelet-like structure, has different and species-specific positions on the ventral part of the epitheca. A position of the ventral pore comparable to A. zhuanum is found in A. concinnum, A. caudatum var. margalefii, A. dexteroporum, and A. luciferelloides (Nézan et al., 2012; Percopo et al., 2013; Tillmann et al., 2014a; Tillmann and Akselman, 2016). The ridge of the pore plate bordering the ventral pore displaces to the right in A. concinnum and A. dexteroporum (Percopo et al., 2013; Tillmann et al., 2014a), but not in A. zhuanum. Thus the apical pore complex appears symmetrical in A. zhuanum compared with the former two species. Azadinium caudatum var. margalefii displays a similar position of appearance of the ventral pore as A. zhuanum, but clearly differs in size (mean cell length of $31.3 \mu \mathrm{m})$ and in the ratio of epitheca and hypotheca, and has an antapical horn and spine (Nézan et al., 2012). Azadinium luciferelloides has a very similar position of the ventral pore, but A. zhuanum has only two intercalary plates compared to three intercalary plates of A. luciferelloides (Tillmann and Akselman, 2016). The presence of two anterior intercalary plates in A. zhuanum is particularly unusual, as 
other Azadinium species have three except for A. dalianense (Luo et al., 2013). However, A. zhuanum has four apical plates instead of three in A. dalianense, and they also differ in the location of ventral pore (Table 5). Therefore, A. zhuanum was designated as a new species.

\subsubsection{Azadinium poporum}

Azadinium poporum from Diana Lagoon (Corsica, Mediterranean Sea) fits the original description (Tillmann et al., 2011), and our findings of a group of pores in the second antapical plate support the notion that this might be a common feature in $A$. poporum (Luo et al., 2016; Tillmann et al., 2016), but more data on other A. poporum strains are needed. Azadinium poporum has been reported from the North Sea, from East Asia, New Zealand, Argentina, and from the Gulf of Mexico (Potvin et al., 2011; Tillmann et al., 2011; Gu et al., 2013; Smith et al., 2015; Luo et al. 2016; Tillmann et al., 2016 ) (Table 5). Here its distribution is extended to the Mediterranean Sea and French Atlantic for the first time, further supporting the view that A. poporum is a more widely distributed species.

\subsubsection{Azadinium dalianense}

Azadinium dalianense from the French Atlantic fits the original description regarding the presence of three apical plates, two anterior intercalary plates and the location of the ventral pore (Luo et al., 2013). A group of pores on the second antapical plate was not mentioned in the original description, but they are present on 
the type material (Gu, personal observations), on the Argentine specimens (Tillmann and Akselman, 2016), and on the French strain reported here. Such kind of dense pores on plate $2^{\prime \prime \prime \prime}$ are also present in A. zhuanum and A. poporum and thus may reflect a common but unknown function. Moreover, a similar area of pores at the same position on plate $2^{\prime \prime \prime \prime}$, though arranged as a depressed field of pores bordered by a rim, is present in Amphidoma languida (Tillmann et al., 2012a). Only a small fraction of cells of the type strain of A. dalianense from China showed a small antapical spine in culture (Luo et al., 2013) In the French strain and in the field sample from Argentina, however, all cells identified as A. dalianense had an antapical spine (Tillmann and Akselman, 2016; present study), suggesting that such kind of spines may be strain specific and/or partially lost in the Chinese culture due to different culture conditions. The findings of A. dalianense in Asia, and South America (Luo et al., 2013; Tillmann and Akselman, 2016), and now also in Europe, also imply that this species, as with $A$. poporum, has a wider distribution.

\subsection{Phylogeny and genetic differentiation}

Our results support the monophyly of both the family Amphidomataceae and genus Azadinium (Tillmann et al., 2012a). Azadinium zhuanum shares the unusual presence of only two intercalary plates with $A$. dalianense, but they are phylogenetically distant probably because they differ in the number of apical plates. The close relationship between A. zhuanum and A. polongum in the molecular phylogeny is surprising, but clearly indicates that a presumable loss of the small medium intercalary plate (present 
in other Azadinium species) in A. zhuanum and A. dalianense has evolved independently. The placement of $A$. zhuanum next to A. polongum is moreover surprising as both taxa differ in the position of the ventral pore, being on the left side (A. polongum) and on the right side (A. zhuanum) of the epitheca. As pointed out by Tillmann et al (2014a), interpretation of character evolution within Azadinium is challenging, but nevertheless the position of the ventral pore appears not only as a diagnostic, but also as a phylogenetically informative trait. Species with a ventral pore on the right lateral side (A. concinnum, A. caudatum, A. dexteroporum, and A. zhuanum) diverge early in the tree, suggesting that a ventral pore on the right side, as it is also found for Amphidoma languida, might be an ancestral trait of the group. With an evolutionary displacement of the ventral pore from the right to the left lateral side as a plausible scenario inferred from the molecular phylogenetic trees, the ventral pore located on the left lateral side in A. polongum must be interpreted as result of an independent development.

Genetic differentiation in Azadinium poporum has been reported previously and so far four ribotypes have been identified. However, our results demonstrate genetic differences within a single ribotype (A) for the first time. Prior to this study, all strains of ribotype A (North Sea and New Zealand) shared identical LSU sequences (Smith et al., 2015). A. poporum from the Gulf of Mexico showed slight LSU and ITS differences from those of ribotypes $\mathrm{B}$ and $\mathrm{C}$, thus previously designated as ribotype $\mathrm{D}$ (Luo et al., 2016), but are here moved to ribotype C. The high variability of LSU sequences challenges the rapid detection of A. poporum using a FISH probe, but 
sequences are conservative regarding the fragments for TaqMan MGB probe and qPCR primers (Toebe et al., 2013), thus these probes are supposed to detect the new strains as well.

The French Atlantic A. dalianense strain shows genetic differences to the Chinese strain, sharing only $94 \%$ similarity in their ITS sequences. These differences are larger than those found in the A. poporum strains among all the ribotypes (96\%) and also among the two A. dexteroporum strains (95\%). It is worth noting that the two varieties of A. caudatum share $97 \%$ similarity in ITS sequences. The genetic distance of two strains of A. dalianense reaches 0.06 , slightly larger than the suggested threshold value (0.04) at the interspecific level (Litaker et al., 2007). So far, A. dalianense has also been reported in Argentina, but molecular sequences from the South Atlantic populations are not yet available. Additional strains of A. dalianense from different locations are needed for a thorough examination of genetic variation within this species.

\subsection{AZA profiles}

The production of AZA-2 for Azadinium poporum as reported here for the Mediterranean strain (ribotype A) has also been reported for A. poporum strains from China (ribotypes B and C, Krock et al., 2014), Argentina (ribotype C, Tillmann et al., 2016), and from the Gulf of Mexico (ribotype C as reported here, Luo et al., 2016), and thus is not related to a specific ribotype or geographic origin. The presence of both AZA 2 and its phosphated form together as it has been previously reported for 
the Argentinian strains (Tillmann et al., 2016) and from the Gulf of Mexico strain (Luo et al., 2016) suggests that this is more the rule rather than the exception for A.poporum strains, so it is probable that AZA 2 and its phosphated form will be also shown for the Chinese strains upon further re-investigation.

AZA-2 production of the Mediterranean A. poporum might be responsible for AZA-2 recently detected in mussels collected in Adriatic Sea (Bacchiocchi et al., 2015). Azadinium dexteroporum from the Gulf of Naples contained a number of different AZA but did not produce AZA-2 (Rossi et al., 2016). However, other Azadinium species are likely present in the Mediterranean (Busch et al., 2016) and thus might contribute to the AZA-2 shellfish contamination, too.

AZA-1 and AZA-2 were detected in shellfish collected in Brittany, France (Braña Magdalena et al., 2003; Amzil et al., 2008). This corresponds to the toxin profile of $A$. spinosum, but in fact that Azadinium species has not been observed in Brittany so far. The finding of A. poporum in the French Atlantic now suggests that it may contribute to these toxins. Unfortunately, up to now the efforts to obtain cultures of A. poporum from the French Atlantic to prove and analyze the AZA production potential of French Atlantic A. poporum has failed, which will be the focus of future work. In consideration of the genetic differentiation of Azadinium at inter-specific and intra-specific level, and the qualitative and quantitative variability of AZA production in Azadinium species, e.g. A. poporum (Krock et al., 2014; Li et al., 2016), it would be desirable to identify genes involved in AZA biosynthesis. As it has been shown for paralytic shellfish toxins and species of the genus Alexandrium (Murray et al., 2016), 
this would allow a rapid and more direct molecular method to quantify actual toxic Azadinium species from marine waters.

\section{Acknowledgements}

This work was supported by the National Natural Science Foundation of China (41376170, 41676117), Bilateral International Cooperation Fund of SOA (HC170301) and the Helmholtz-Gemeinschaft Deutscher Forschungszentren through the research programme PACES II of the Alfred Wegener Institut-Helmholtz Zentrum für Polarund Meeresforschung. We thank Yoann Baldi for sediment sampling from Corsica. Thanks to Philipp Hess and Manoella Sibat for maintenance of the French Azadinium dalianense strain.

\section{References}

Adachi, M., Sake, Y., Ishida, Y., 1996. Analysis of Alexandrium (Dinophyceae) species using sequences of the 5.8s ribosomal DNA and internal transcribed spacer regions. J. Phycol. 32(3), 424-432.

Amzil, Z., Sibat, M., Royer, F., Savar, V., 2008. First report on azaspiracid and yessotoxin groups detection in French shellfish. Toxicon 52(1), 39-48.

Bacchiocchi, S., Siracusa, M., Ruzzi, A., Gorbi, S., Ercolessi, M., Cosentino, M.A., Ammazzalorso, P., Orletti, R., 2015. Two-year study of lipophilic marine toxin profile in mussels of the North-central Adriatic Sea: First report of azaspiracids in Mediterranean seafood. Toxicon 108, 115-125. 
Boc, A., Diallo, A.B., Makarenkov, V., 2012. T-REX: a web server for inferring, validating and visualizing phylogenetic trees and networks. Nucleic Acids Res. 40 (Web Server issue), W573-W579.

Braña Magdalena, A., Lehane, M., Krys, S., Fernández, M.L., Furey, A., James, K.J., 2003. The first identification of azaspiracids in shellfish from France and Spain. Toxicon 42(1), 105-108.

Busch, J.A., Andree, K.B., Diogène, J., Fernández-Tejedor, M., Toebe, K., John, U., Krock, B., Tillmann, U., Cembella, A.D., 2016. Toxigenic algae and associated phycotoxins in two coastal embayments in the Ebro Delta (NW Mediterranean). Harmful Algae 55, 191-201.

Carroll, H., Beckstead, W., O'Connor, T., Ebbert, M., Clement, M., Snell, Q., McClellan, D., 2007. DNA reference alignment benchmarks based on tertiary structure of encoded proteins. Bioinformatics 23(19), 2648-2649.

Daugbjerg, N., Hansen, G., Larsen, J., Moestrup, Ø., 2000. Phylogeny of some of the major genera of dinoflagellates based on ultrastructure and partial LSU rDNA sequence data, including the erection of three new genera of unarmoured dinoflagellates. Phycologia 39(4), 302-317.

Doyle, J.J., Doyle, J.L., 1987. A rapid DNA isolation procedure for small quantities of fresh leaf tissu. Phytochemical Bulletin 19, 11-15.

Gu, H., Luo, Z., Krock, B., Witt, M., Tillmann, U., 2013. Morphology, phylogeny and azaspiracid profile of Azadinium poporum (Dinophyceae) from the China Sea. Harmful Algae 21-22, 64-75. 
Guillard, R.R.L., Ryther, J.H., 1962. Studies of marine planktonic diatoms. I. Cyclotella nana Hustedt, and Detonula confervacea (Cleve) Gran. Can. J. Microbiol. $8(2), 229-239$.

Hall, T.A., 1999. BioEdit: a user-friendly biological sequence alignment editor and analysis program for Windows 95/98/NT. Nucleic Acids Symp. Ser. 41, 95-98.

Katoh, K., Standley, D.M., 2013. MAFFT multiple sequence alignment software version 7: improvements in performance and usability. Mol. Biol. Evol. 30(4), $772-780$.

Krock, B., Tillmann, U., Voß, D., Koch, B.P., Salas, R., Witt, M., Potvin, É., Jeong, H.J., 2012. New azaspiracids in Amphidomataceae (Dinophyceae). Toxicon 60(5), $830-839$.

Krock, B., Tillmann, U., Witt, M., Gu, H., 2014. Azaspiracid variability of Azadinium poporum (Dinophyceae) from the China Sea. Harmful Algae 36(0), 22-28.

Li, A., Jiang, B., Chen, H., Gu, H., 2016. Growth and toxin production of Azadinium poporum strains in batch cultures under different nutrient conditions. Ecotoxicol. Environ. Saf. 127, 117-126.

Litaker, W.R., Vandersea, M.W., Kibler, S.R., Reece, K.S., Stokes, N.A., Lutzoni, F.M., Yonish, B.A., West, M.A., Black, M.N.D., Tester, P.A., 2007. Recognizing dinoflagellate species using ITS rDNA sequences. J. Phycol. 43, 344-355.

Luo, Z., Gu, H., Krock, B., Tillmann, U., 2013. Azadinium dalianense, a new dinoflagellate species from the Yellow Sea, China. Phycologia 52(6), 625-636.

Luo, Z., Krock, B., Mertens, K.N., Price, A.M., Turner, R.E., Rabalais, N.N., Gu, H., 
2016. Morphology, molecular phylogeny and azaspiracid profile of Azadinium poporum (Dinophyceae) from the Gulf of Mexico. Harmful Algae 55, 56-65.

Medlin, L., Elwood, H.J., Stickel, S., Sogin, M.L., 1988. The characterization of enzymatically amplified eukaryotic 16S-like rRNA-coding regions. Gene 71(2), 491-499.

Murray, S.A., Suggett, D.J., Doblin, M.A., Kohli, G.S., Seymour, J.R., Fabris, M., Ralph, P.J., 2016. Unravelling the functional genetics of dinoflagellates: a review of approaches and opportunities. Perspect. in Phycol. 3(1), 37-52.

Nézan, E., Tillmann, U., Bilien, G., Boulben, S., Chèze, K., Zentz, F., Salas, R., Chomérat, N., 2012. Taxonomic revision of the dinoflagellate Amphidoma caudata: transfer to the genus Azadinium (Dinophyceae) and proposal of two varieties, based on morphological and molecular phylogenetic analyses. J. Phycol. 48, 925-939.

Nézan, E., Siano, R., Boulben, S., Six, C., Bilien, G., Chèze, K., Duval, A., Le Panse, S., Quéré, J., Chomérat, N., 2014. Genetic diversity of the harmful family Kareniaceae (Gymnodiniales, Dinophyceae) in France, with the description of Karlodinium gentienii sp . nov. : a new potentially toxic dinoflagellate. Harmful Algae $40,75-91$.

Nylander, J.A.A., Wilgenbusch, J.C., Warren, D.L., Swofford, D.L., 2008. AWTY (are we there yet?): a system for graphical exploration of MCMC convergence in Bayesian phylogenetics. Bioinformatics 24(4), 581-583.

Percopo, I., Siano, R., Rossi, R., Soprano, V., Sarno, D., Zingone, A., 2013. A new potentially toxic Azadinium species (Dinophyceae) from the Mediterranean Sea, A. 
dexteroporum sp. nov. J. Phycol. 49(5), 950-966.

Posada, D., 2008. jModelTest: phylogenetic model averaging. Mol. Biol. Evol. 25(7), $1253-1256$.

Potvin, É., Jeong, H.J., Kang, N.S., Tillmann, U., Krock, B., 2011. First report of the photosynthetic dinoflagellate genus Azadinium in the Pacific Ocean: Morphology and molecular characterization of Azadinium cf. poporum. J. Eukaryot. Microbiol. 59, $145-156$.

Ronquist, F., Huelsenbeck, J.P., 2003. MrBayes 3: Bayesian phylogenetic inference under mixed models. Bioinformatics 19(12), 1572-1574.

Rossi, R., Dell'Aversano, C., Krock, B., Ciminiello, P., Percopo, I., Tillmann, U., Soprano, V., Zingone, A., 2017. Mediterranean Azadinium dexteroporum (Dinophyceae) produces six novel azaspiracids and azaspiracid-35: a structural study by a multi-platform mass spectrometry approach. Anal Bioanal Chem409(4), $1121-1134$.

Salas, R., Tillmann, U., John, U. John, U., Kilcoyne, J., Burson, A., Cantwell, C., Hess, P., Jauffrais, T., Silke, J., 2011. The role of Azadinium spinosum (Dinophyceae) in the production of azaspiracid shellfish poisoning in mussels. Harmful Algae 10, $774-783$.

Scholin, C.A., Herzog, M., Sogin, M., Anderson, D.M., 1994. Identification of group-and strain-specific genetic markers for globally distributed Alexandrium (dinophyceae).II. sequence analysis of a fragment of the LSU rRNA gene. J. Phycol. 30(6), 999-1011. 
Smith, K.F., Rhodes, L., Harwood, D.T., Adamson, J., Moisan, C., Munday, R., Tillmann, U., 2015. Detection of Azadinium poporum in New Zealand: the use of molecular tools to assist with species isolations. J. Appl. Phycol. 28(2), 1125-1132.

Stamatakis, A., 2006. RAxML-VI-HPC: maximum likelihood-based phylogenetic analyses with thousands of taxa and mixed models. Bioinformatics 22(21), $2688-2690$.

Stein, J.R., 1973. Handbook of Physiological Methods: Culture Methods and Growth Measurements. Cambridge University Press, New York.

Tillmann, U., Akselman, R., 2016. Revisiting the 1991 algal bloom in shelf waters off Argentina: Azadinium luciferelloides sp. nov. (Amphidomataceae, Dinophyceae) as the causative species in a diverse community of other amphidomataceans. Phycol. Res. 64(3), 160-175.

Tillmann, U., Borel, C.M., Barrera, F., Lara, R., Krock, B., Almandoz, G.O., Witt, M., Trefault, N., 2016. Azadinium poporum from the Argentine Continental Shelf, Southwestern Atlantic, produces azaspiracid-2 and azaspiracid-2 phosphate. Harmful Algae 51, 40-55.

Tillmann, U., Elbrächter, M., John, U., Krock, B., 2011. A new non-toxic species in the dinoflagellate genus Azadinium: A. poporum sp. nov. Eur. J. Phycol. 46(1), 74-87. Tillmann, U., Elbrächter, M., John, U., Krock, B., Cembella, A., 2010. Azadinium obesum (Dinophyceae), a new nontoxic species in the genus that can produce azaspiracid toxins. Phycologia 49(2), 169-182.

Tillmann, U., Elbrächter, M., Krock, B., John, U., Cembella, A., 2009. Azadinium 
spinosum gen. et sp. nov. (Dinophyceae) identified as a primary producer of azaspiracid toxins. Eur. J. Phycol. 44(1), 63-79.

Tillmann, U., Gottschling, M., Nézan, E., Krock, B., Bilien, G., 2014a. Morphological and molecular characterization of three new Azadinium species (Amphidomataceae, Dinophyceae) from the Irminger Sea. Protist 165(4), 417-444.

Tillmann, U., Krock, B., Taylor, B. B., 2014b. Azadinium caudatum var. margalefii, a poorly known member of the toxigenic genus Azadinium (Dinophyceae). Mar. Biol. Res. 10, 941-956.

Tillmann, U., Salas, R., Gottschling, M., Krock, B., O'Driscoll, D., Elbrächter, M., 2012a. Amphidoma languida sp. nov. (Dinophyceae) reveals a close relationship between Amphidoma and Azadinium. Protist 163(5), 701-719.

Tillmann, U., Soehner, S., Nézan, E., Krock, B., 2012b. First record of the genus Azadinium (Dinophyceae) from the Shetland Islands, including the description of Azadinium polongum sp. nov. Harmful Algae 20, 142-155.

Tillmann, U., Gottschling, M., Nézan, E., Krock, B., 2015. First records of Amphidoma languida and Azadinium dexteroporum (Amphidomataceae, Dinophyceae) from the Irminger Sea off Iceland. Mar. Biodivers. Rec. 8, 1-11.

Tillmann, U., Trefault, N., Krock, B., Paradapozo, G., Iglesia, R. D. L., Vásquez, M. 2017. Identification of Azadinium poporum (Dinophyceae) in the Southeast Pacific: morphology, molecular phylogeny, and azaspiracid profile characterization. J. Plankton Res. 64(3), 160-175.

Toebe, K., Joshi, A.R., Messtorff, P., Tillmann, U., Cembella, A., John, U., 2013. 
Molecular discrimination of taxa within the dinoflagellate genus Azadinium, the source of azaspiracid toxins. J. Plankton Res. 35(1), 225-230.

\section{Tables}

Table 1

Strains and specimens of Azadinium examined in the present study, including azaspiracids (AZA) production, origin, collection locations and date. N.A. =not analyzed.

\begin{tabular}{|c|c|c|c|c|c|c|c|c|}
\hline Species & Strains & AZA & Origin & Latitude & Longitude & Location & Date & Sequences (SSU/ITS/LSU) \\
\hline A. zhuanum & $\mathrm{T} 10823$ & N.A. & Sediment & $35^{\circ} 59.96^{\prime} \mathrm{N}$ & $121^{\circ} 28.59^{\prime} \mathrm{E}$ & Yellow Sea, China & 2015.12.18 & MF033109/MF033113/MF033118 \\
\hline A. zhuanum & $\mathrm{TlO} 202$ & N.A. & Sediment & $27^{\circ} 28.04^{\prime} \mathrm{N}$ & $121^{\circ} 3.24^{\prime} \mathrm{E}$ & Wenzhou, East China Sea & 2016.1.3 & -/-/MF033119 \\
\hline A. zhuanum & $\mathrm{TIO} 205$ & None & Sediment & $27^{\circ} 28.04^{\prime} \mathrm{N}$ & $121^{\circ} 3.24^{\prime} \mathrm{E}$ & Wenzhou, East China Sea & 2016.1.3 & MF033110/MF033114/MF033120 \\
\hline A. zhuanum & $\mathrm{TlO} 213$ & None & Sediment & $27^{\circ} 28.04^{\prime} \mathrm{N}$ & $121^{\circ} 3.24^{\prime} \mathrm{E}$ & Wenzhou, East China Sea & 2016.1.3 & MF033111/MF033115/MF033121 \\
\hline A. zhuanum & $\mathrm{TIO} 258$ & N.A. & Sediment & $24^{\circ} 31.08^{\prime} \mathrm{N}$ & $118^{\circ} 41.40^{\prime} \mathrm{E}$ & East China Sea & 2016.3.31 & -/-/MF033122 \\
\hline A. poporum & TIO256 & $\begin{array}{l}\text { AZA-2/AZA-2 } \\
\text { phosphate }\end{array}$ & Sediment & $42^{\circ} 7.66^{\prime} \mathrm{N}$ & $9^{\circ} 31.72^{\prime} \mathrm{E}$ & Corsica, France (Mc & 2016.1.18 & MF033112/MF0 \\
\hline A. pol & N.A. & N.A. & Plankton & $48^{\circ} 18.54^{\prime} \mathrm{N}$ & $4^{\circ} 26.88^{\prime} \mathrm{W}$ & Brest Bay, France & 2010.6 .7 & -/-/MF033124 \\
\hline A. poporum & N.A. & N.A. & Plankton & $47^{\circ} 39.42^{\prime} \mathrm{N}$ & $3^{\circ} 12.42^{\prime} \mathrm{W}$ & Etel river inlet, Kerros, France & 2008.6 .9 & -/-/MF033125 \\
\hline A. dalianense & IFR-ADA-01C & None & Plankton & $47^{\circ} 50.09^{\prime} \mathrm{N}$ & $3^{\circ} 57.04^{\prime} \mathrm{W}$ & Concarneau Bay, France & 2013.6.11 & -/MF033117/MF033126 \\
\hline
\end{tabular}


Table 2

Mass transitions $m / z(\mathrm{Q} 1>\mathrm{Q} 3$ mass $)$ and their respective AZA. N.S. = not specified.

\begin{tabular}{|c|c|c|c|}
\hline $\begin{array}{l}\text { Q1 Mass } \\
\text { (Da) }\end{array}$ & $\begin{array}{l}\text { Q3 Mass } \\
\text { (Da) }\end{array}$ & $\begin{array}{l}\text { Collision energy } \\
(\mathrm{CE})[\mathrm{V}]\end{array}$ & AZA \\
\hline 716 & 698 & 40 & AZA-33 \\
\hline 796 & 778 & 40 & AZA-33 phosphate \\
\hline 816 & 798 & 40 & AZA-39 \\
\hline 816 & 348 & 70 & AZA-39 \\
\hline 828 & 810 & 40 & AZA-3, AZA-43 \\
\hline 828 & 658 & 70 & AZA-3 \\
\hline 830 & 812 & 40 & AZA-38 \\
\hline 830 & 348 & 70 & AZA-38 \\
\hline 842 & 672 & 70 & AZA-1 \\
\hline 842 & 824 & 40 & AZA-1, AZA-40 \\
\hline 842 & 348 & 70 & AZA-40 \\
\hline 844 & 826 & 40 & AZA-4, AZA-5 \\
\hline 846 & 828 & 40 & AZA-37 \\
\hline 846 & 348 & 70 & AZA-37 \\
\hline 854 & 670 & 70 & AZA-41 \\
\hline 854 & 836 & 40 & AZA-41 \\
\hline 854 & 360 & 70 & AZA-41 \\
\hline 856 & 672 & 70 & AZA-2 \\
\hline 856 & 838 & 40 & AZA-2 \\
\hline 858 & 840 & 40 & $\begin{array}{l}\text { AZA-7, AZA-8, AZA-9, AZA-10, } \\
\text { AZA-36 }\end{array}$ \\
\hline 858 & 348 & 70 & AZA-36 \\
\hline 860 & 842 & 40 & AZA-59 \\
\hline 868 & 850 & 40 & AZA-55 \\
\hline 868 & 362 & 70 & AZA-55 \\
\hline 870 & 852 & 40 & AZA-54 \\
\hline 870 & 360 & 70 & AZA-42, AZA-54 \\
\hline 872 & 854 & 40 & AZA-11, AZA-12 \\
\hline 884 & 866 & 40 & AZA-56 \\
\hline 896 & 878 & 40 & AZA-39 phosphate \\
\hline 910 & 892 & 40 & N.S. \\
\hline 920 & 804 & 40 & N.S. \\
\hline 920 & 348 & 70 & N.S. \\
\hline 922 & 904 & 40 & AZA-1 phosphate \\
\hline 926 & 908 & 40 & AZA-37 phosphate \\
\hline 928 & 910 & 40 & N.S. \\
\hline 928 & 348 & 70 & N.S. \\
\hline 936 & 918 & 40 & AZA-2 phosphate \\
\hline 936 & 802 & 40 & AZA-2 phosphate \\
\hline 952 & 818 & 40 & AZA-11 phosphate \\
\hline
\end{tabular}


Table 3

Partial LSU sequences comparison of Azadinium zhuanum,A. dalianense and A. poporum strains. The percentage refers to the similarity out of partial LSU sequences (682 bp); the numeral refers to pairwise genetic distance.

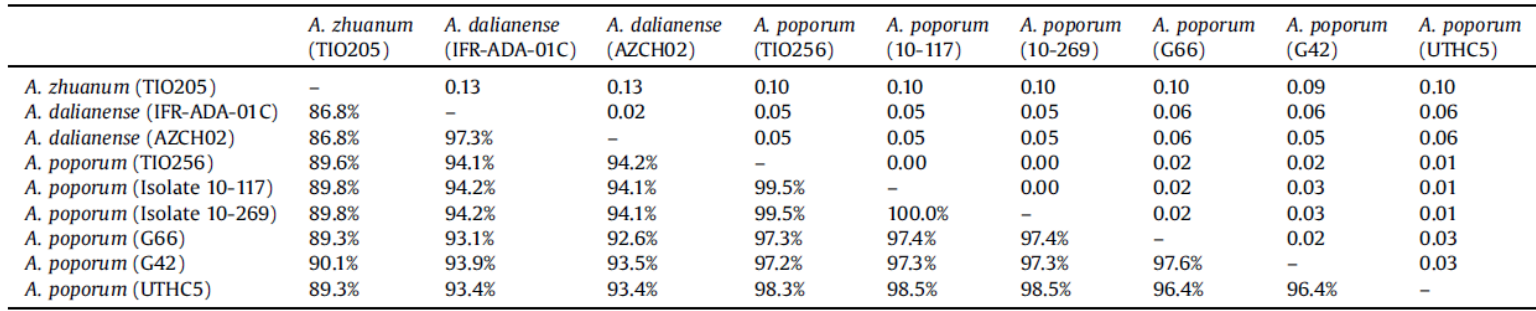

Table 4

ITS sequences comparison of Azadinium zhuanum, A. dalianense and A. poporum strains. The percentage refers to the similarity and the numeral refers to pairwise genetic distance.

\begin{tabular}{|c|c|c|c|c|c|c|c|}
\hline & $\begin{array}{l}\text { A. zhuanum } \\
\text { (TIO205) }\end{array}$ & $\begin{array}{l}\text { A. dalianense } \\
\text { (IFR-ADA-01C) }\end{array}$ & $\begin{array}{l}\text { A. dalianense } \\
(\mathrm{AZCH02})\end{array}$ & $\begin{array}{l}\text { A. poporum } \\
\text { (TIO256) }\end{array}$ & $\begin{array}{l}\text { A. poporum } \\
\text { (UTHC5) }\end{array}$ & $\begin{array}{l}\text { A. poporum } \\
\text { (G66) }\end{array}$ & $\begin{array}{l}\text { A. poporum } \\
\text { (G42) }\end{array}$ \\
\hline A. dalianense (IFR-ADA-01C) & $81.0 \%$ & - & 0.06 & 0.09 & 0.09 & 0.10 & 0.10 \\
\hline A. dalianense ( $\mathrm{AZCHO2})$ & $78.9 \%$ & $93.6 \%$ & - & 0.09 & 0.08 & 0.09 & 0.09 \\
\hline A. poporum (UTHC5) & $80.4 \%$ & $89.5 \%$ & $91.0 \%$ & $98.3 \%$ & - & 0.02 & 0.02 \\
\hline A. poporum (G66) & $80.2 \%$ & $88.9 \%$ & $90.4 \%$ & $97.5 \%$ & $97.3 \%$ & - & 0.02 \\
\hline A. poporum (G42) & $80.2 \%$ & $89.1 \%$ & $90.3 \%$ & $96.3 \%$ & $97.5 \%$ & $97.6 \%$ & - \\
\hline
\end{tabular}

Table 5

Morphological comparison of Azadinium zhuanum with some similar Azadinium species.

\begin{tabular}{|c|c|c|c|c|c|c|c|}
\hline & A. zhuanum & A. luciferelloides & A. poporum & $\begin{array}{l}\text { A. caudatum } \\
\text { var. margalefii }\end{array}$ & A. dexteroporum & A. dalianense & A. concinnum \\
\hline $\begin{array}{l}\text { Length range } \\
\text { (mean) }\end{array}$ & $16.8-21.6(18.5)$ & $9.4-14.1(11.1)^{a}$ & $11.3-16.3(13.0)$ & $25.0-42.1$ & $7.0-10.0(8.5)$ & $\begin{array}{l}11.9-18.0 \\
(13.9)\end{array}$ & $8.0-11.5(9.5)$ \\
\hline $\begin{array}{l}\text { Width range } \\
\text { (mean) }\end{array}$ & $12.5-18.8(14.8)$ & $7.6-11.6(9.1)^{a}$ & $8.0-11.6(9.8)$ & $18.4-30.0$ & $5.0-8.0(6.2)$ & $8.3-12.7(10.1)$ & $5.6-8.3(6.6)$ \\
\hline $\mathrm{L} / \mathrm{W}$ ratio & 1.25 & 1.4 & 1.3 & 1.2 & 1.4 & 1.4 & 1.4 \\
\hline $\begin{array}{l}\text { Number apical/ } \\
\text { intercalary } \\
\text { plates }\end{array}$ & $4 / 2$ & $4 / 3$ & $4 / 3$ & $4 / 3$ & $4 / 3$ & $3 / 2$ & $4 / 3$ \\
\hline Antapical spine & spine & spine & no & $\begin{array}{l}\text { short horn, } \\
\text { long spine }\end{array}$ & spine & short spine & spine \\
\hline Stalked pyrenoid & 1 & unknown & up to 4 & none & 1 & up to 2 & none \\
\hline $\begin{array}{l}1^{\prime \prime} \text { in contact with } \\
1 \mathrm{a}\end{array}$ & yes & yes & yes & yes & yes & yes & no \\
\hline vp position & $\begin{array}{l}\text { pore plate, right } \\
\text { side }\end{array}$ & $\begin{array}{l}\text { pore plate, right } \\
\text { side }\end{array}$ & pore plate, left side & $\begin{array}{l}\text { pore plate, } \\
\text { right side }\end{array}$ & end of pore plate, right side & $\begin{array}{l}\text { pore plate, left } \\
\text { side }\end{array}$ & $\begin{array}{l}\text { pore plate, } \\
\text { right side }\end{array}$ \\
\hline $\begin{array}{l}\text { Pore plate } \\
\text { symmetry }\end{array}$ & $\begin{array}{l}\text { suture to } 1^{\prime} \\
\text { almost } \\
\text { symmetric }\end{array}$ & $\begin{array}{l}\text { suture to } 1^{\prime} \\
\text { almost } \\
\text { symmetric }\end{array}$ & $\begin{array}{l}\text { suture to } 1^{\prime} \text { slightly } \\
\text { asymmetric, left side more } \\
\text { apical }\end{array}$ & $\begin{array}{l}\text { suture to } 1^{\prime} \\
\text { almost } \\
\text { symmetric }\end{array}$ & $\begin{array}{l}\text { suture to } 1^{\prime} \text { strongly } \\
\text { asymmetric, left side more } \\
\text { apical }\end{array}$ & $\begin{array}{l}\text { suture to } 1^{\prime} \\
\text { almost } \\
\text { symmetric }\end{array}$ & $\begin{array}{l}\text { suture to } 1^{\prime} \\
\text { almost } \\
\text { symmetric }\end{array}$ \\
\hline Shape of $1^{\prime}$ plate & $\begin{array}{l}\text { wide posteriorly, } \\
\text { narrow } \\
\text { anteriorly }\end{array}$ & $\begin{array}{l}\text { narrow } \\
\text { posteriorly }\end{array}$ & wide posteriorly & $\begin{array}{l}\text { narrow } \\
\text { posteriorly }\end{array}$ & narrow posteriorly & $\begin{array}{l}\text { wide } \\
\text { posteriorly }\end{array}$ & $\begin{array}{l}\text { narrow } \\
\text { posteriorly }\end{array}$ \\
\hline $\begin{array}{l}\text { Relative size first } \\
\text { and last } \\
\text { intercalary }\end{array}$ & large & small & large & small & small & large & small \\
\hline $\begin{array}{l}\text { Relative size } \\
\text { apical plates }\end{array}$ & small & small & medium & medium & small & medium & small \\
\hline AZAs & none & not tested & $\begin{array}{l}\text { AZA-2, }-11,-36,-37,-40 \\
-41,-42 ; \text { none (strain } \\
\text { specific) }\end{array}$ & none & $\begin{array}{l}\text { 3-epi-AZA-7, AZA-54, - } 55,-56 \\
-57,-58 ; \text { none (strain specific) }\end{array}$ & none & none \\
\hline Records & AP & SA & NS, AP, SA, GF, SP, Med & Med, NS, NA & Med, NA, SA & AP, SA & NA \\
\hline Reference & a & b & a, c, d, e, f, g h, i & $\mathrm{j}, \mathrm{k}$ & $\mathrm{b}, \mathrm{l}, \mathrm{m}, \mathrm{n}$ & $\mathrm{a}, \mathrm{b}, \mathrm{o}$ & $\mathrm{p}$ \\
\hline
\end{tabular}

Records: AP: Asian Pacific; SA: Southwestern Atlantic; NS: North Sea; GF: Gulf of Mecico; SP: Southeast Pacific; NA: North Atlantic. Med: Mediterranean,

References (a) This study; (b) Tillmann and Akselman (2016); (c) Tillmann et al. (2011); (d) Potvin et al. (2011); (e) Krock et al. (2012); (f) Gu et al. (2013); (g) Tillmann et al. (2016); (h) Luo et al. (2016); (i) Tillmann et al. (2017); (j) N\&zan et al. (2012); (k) Tillmann et al. (2014b); (l) Percopo et al. (2013); (m) Tillmann et al. (2015); (n) Rossi et al. (2017); (o) Luo et al. (2013); (p) Tillmann et al. (2014a).

a These size estimates are based on SEM only. 


\section{Figure}

Fig. 1. LM of live cells and cysts of Azadinium zhuanum strain TIO213. (A) Ventral

view, showing the chloroplast (c), pyrenoid (p) and a large presumable pusule

(Pu). (B) Ventral view, showing a large nucleus $(\mathrm{N})$ and a pyrenoid (p). (C)

Ventral view, showing a large nucleus (Sybr Green staining). (D) A living cyst

formed in culture.

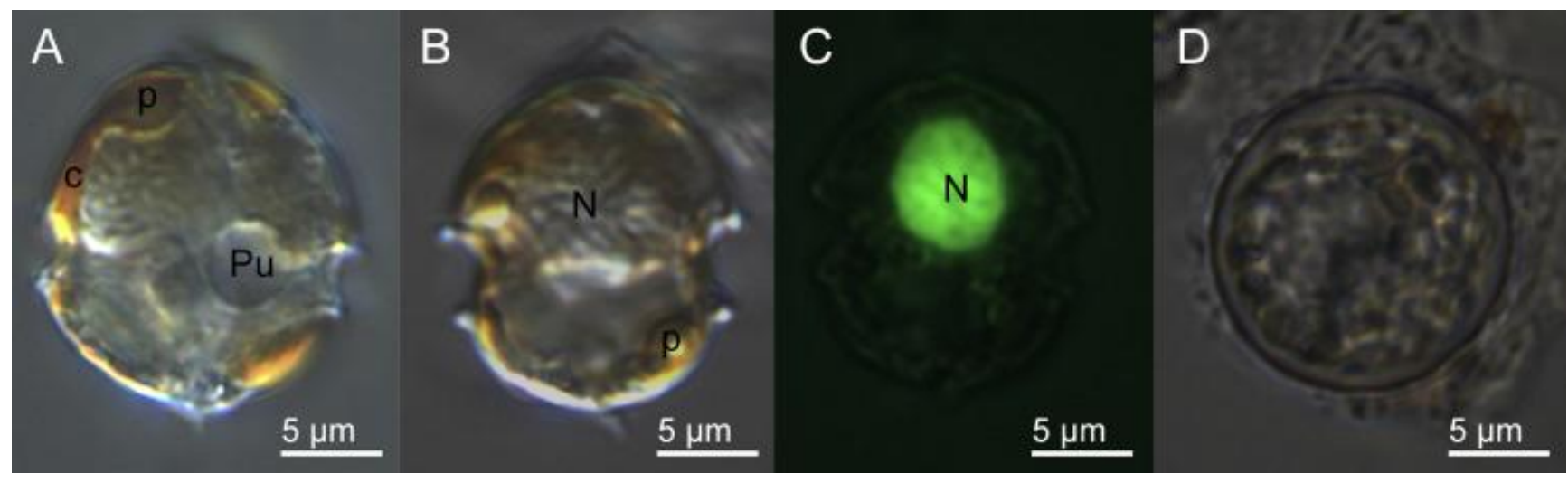


Fig. 2. Scanning electron micrographs of vegetative cells of Azadinium zhuanum strain TIO205. (A) Ventral view showing the round epitheca and hypotheca with a conspicuous antapical spine. (B) Dorsal view showing two anterior intercalary plates (1a, 2a). (C) Apical view showing four apical plates $\left(1^{\prime}-4^{\prime}\right)$, two anterior intercalary (1a, 2a) plates and six precingular plates $\left(1^{\prime \prime}-6^{\prime \prime}\right)$. (D) Antapical view showing six postcingular plates $\left(1^{\prime \prime \prime}-6^{\prime \prime \prime}\right)$ and two antapical plates (1"'"', $\left.2^{\prime \prime \prime \prime}\right)$ of unequal size. $\mathrm{Sa}=$ anterior sulcal plate, $\mathrm{Sp}=$ posterior sulcal plate.
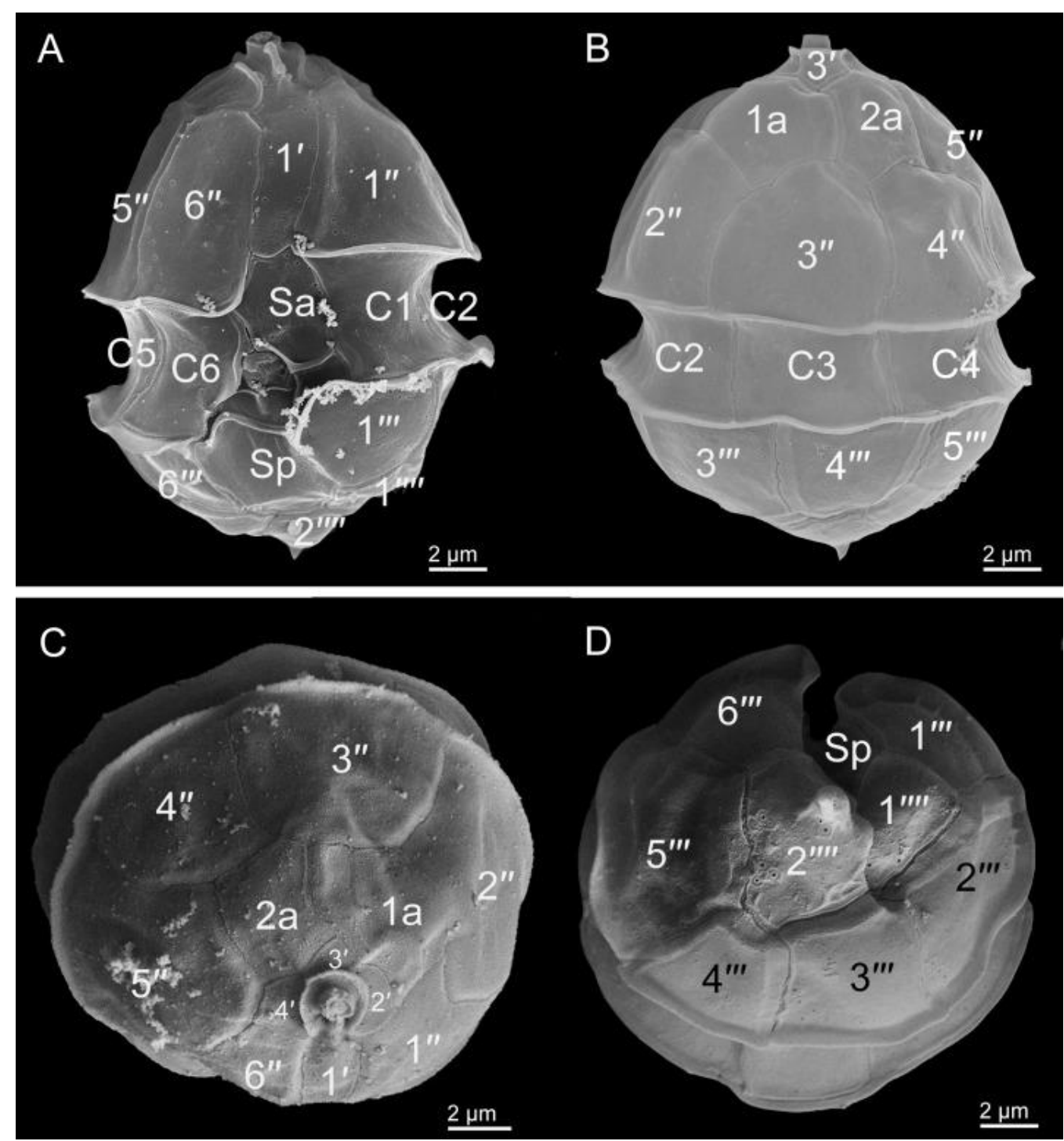
Fig. 3. Scanning electron micrographs of vegetative cells of Azadinium zhuanum strain TIO205. (A) Apical view showing four apical plates $\left(1^{\prime}-4^{\prime}\right)$ and pore plate (Po). (B) Apical view showing four apical plates $\left(1^{\prime}-4^{\prime}\right)$, the cover plate (cp), canal plate (X) and ventral pore (vp). (C) Internal view of the sulcus showing an anterior sulcal plate (Sa), a median sulcal plate $(\mathrm{Sm})$, a right sulcal plate (Sd), a left sulcal plate (Ss), and a posterior sulcal plate (Sp). (D) Sulcal plates showing the $\mathrm{Sa}, \mathrm{Sm}, \mathrm{Sd}$, Ss, and $\mathrm{Sp}$. (E) Lateral view showing six cingular plates $(\mathrm{C} 1-\mathrm{C} 6)$. (F) Internal view of the hypotheca showing a group of pores on the dorsal side of plate $2^{\prime \prime \prime \prime}$.
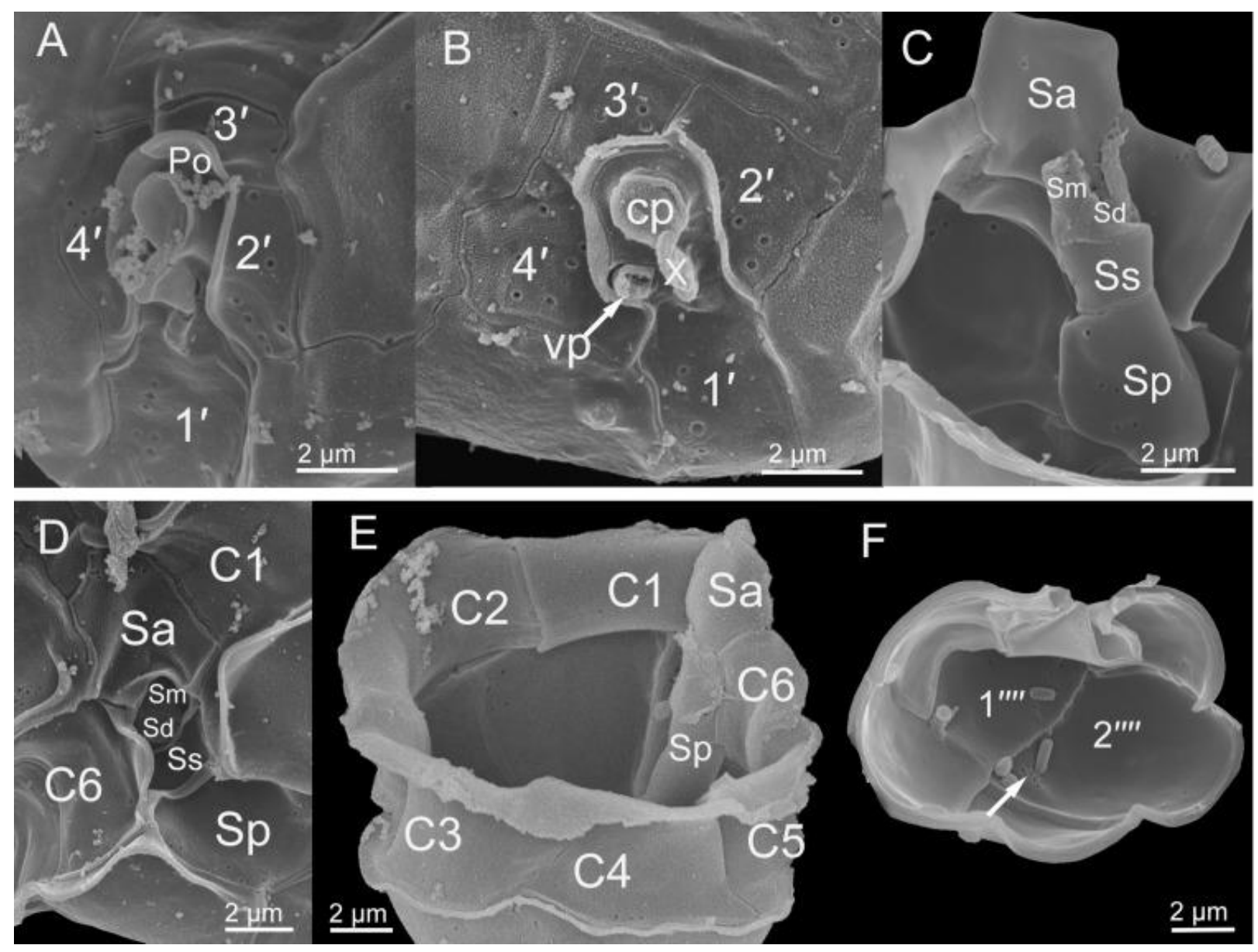
Fig. 4. Interpreted tabulation of Azadinium zhuanum. (A) Ventral view; (B) Dorsal view; (C) Apical view; (D) Antapical view. Short arrows in (C) and (D) indicate the direction of plate overlap. The black triangle in (D) indicates the position of the antapical spine.

A

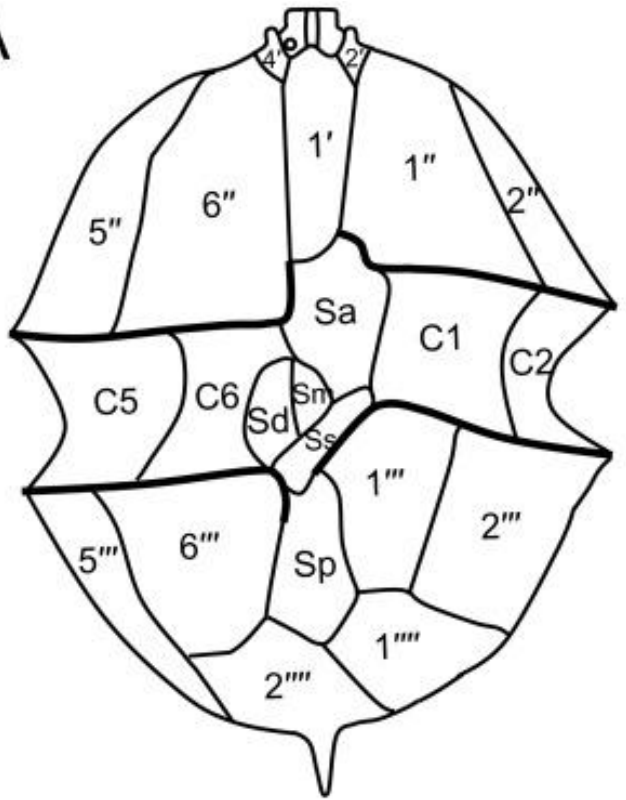

C

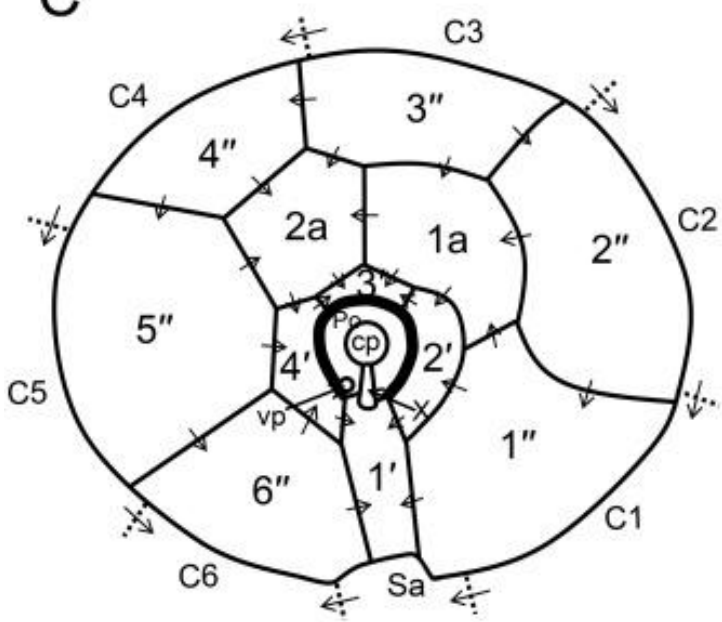

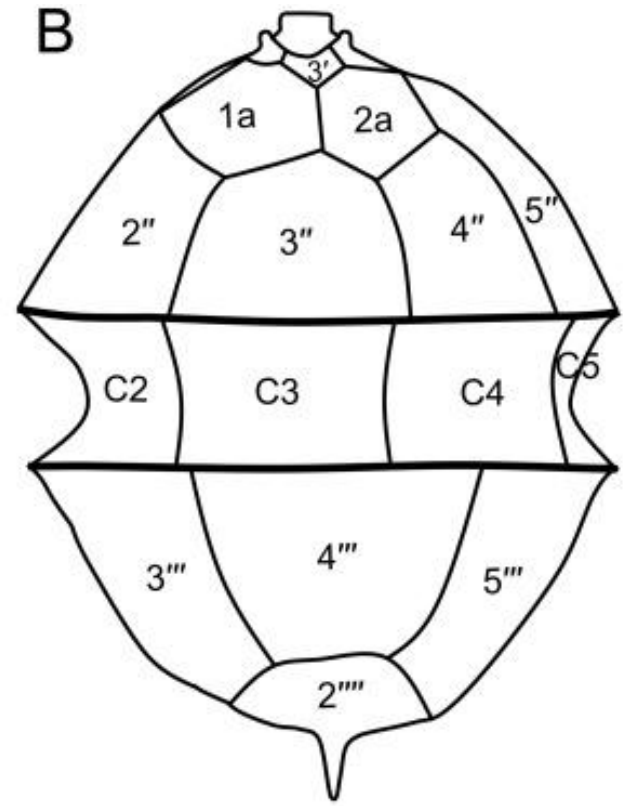

D

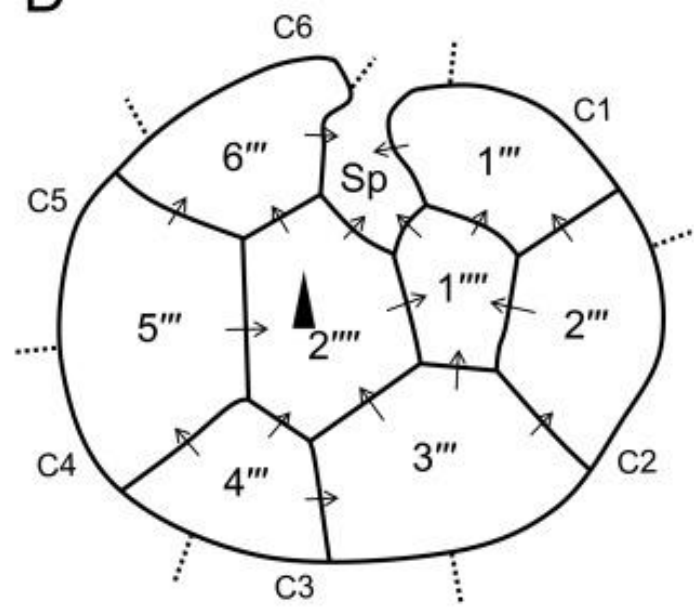


Fig. 5. Scanning electron micrographs of vegetative cells of Azadinium poporum strain TIO256. (A) Ventral view showing the conical epitheca and round hypotheca. (B) Dorsal view showing three anterior intercalary plates (1a, 2a and 3a). (C) Sulcal plates showing an anterior sulcal plate (Sa), a median sulcal plate $(\mathrm{Sm})$, a right sulcal plate $(\mathrm{Sd})$, a left sulcal plate $(\mathrm{Ss})$, and a posterior sulcal plate (Sp). (D) Apical view showing four apical plates $\left(1^{\prime}-4^{\prime}\right)$, pore plate (Po), cover plate (cp), canal plate (X), and ventral pore (vp). (E) Dorsal view, showing three anterior intercalary plates (1a, 2a, and 3a) and the five precingular plates ( 1 " 5"). (F) Antapical view showing six postcingular plates $\left(1^{\prime \prime \prime}-6^{\prime \prime \prime}\right)$ and two antapical plates (1'"', $\left.2^{\prime \prime \prime \prime}\right)$ of unequal size. $(\mathrm{G})$ Detail of plate $2^{\prime \prime \prime \prime}$ showing a group of pores on the dorsal side.
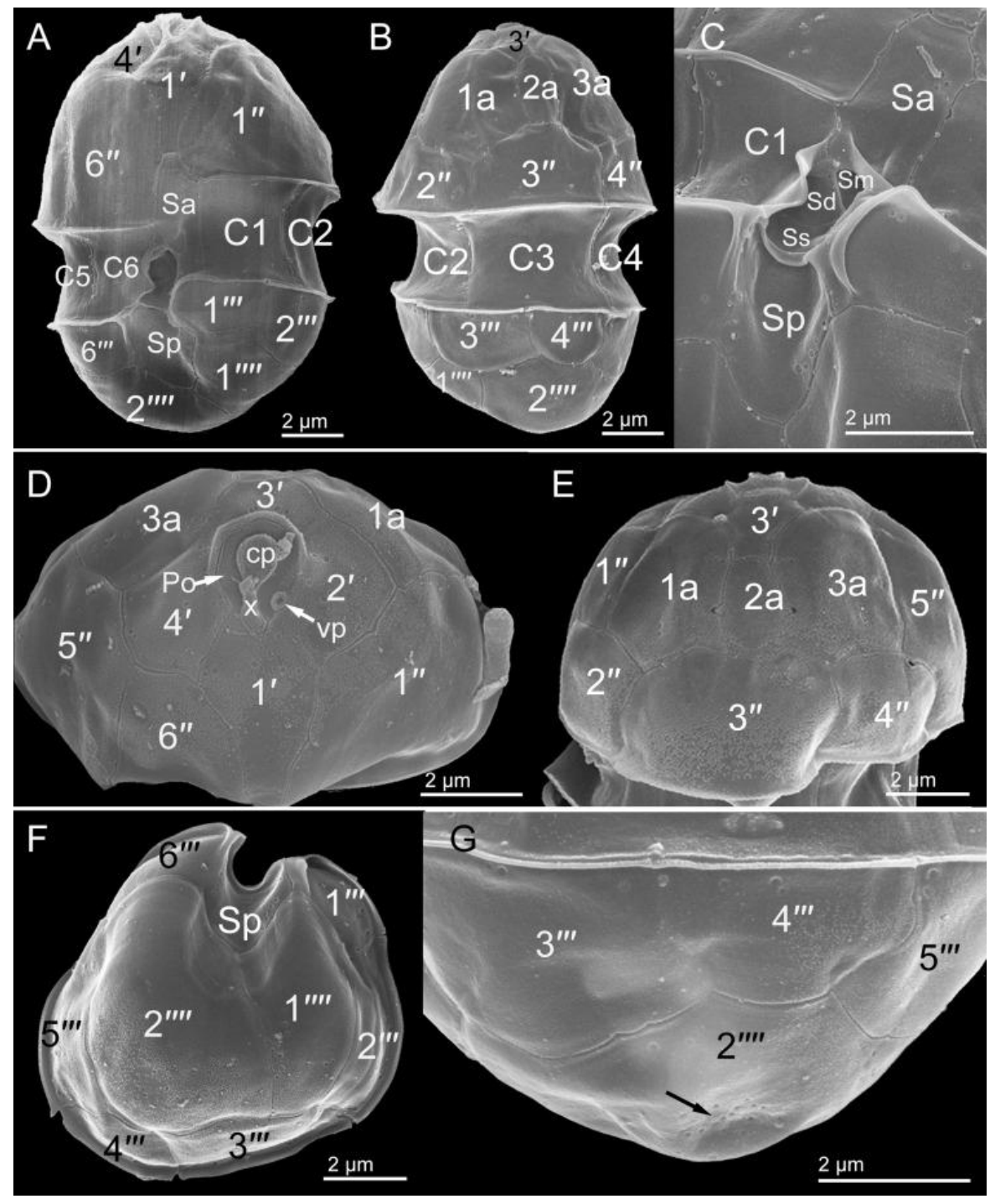
Fig. 6. Scanning electron micrographs of vegetative cells of Azadinium dalianense strain IFR-ADA-01C. (A) Ventral view showing the conical epitheca and round hypotheca with a small antapical spine. (B) Dorsal view showing two anterior intercalary plates (1a, 2a). (C) Apical view showing three apical plates $\left(1^{\prime}-3^{\prime}\right)$, two anterior intercalary plates $(1 \mathrm{a}, 2 \mathrm{a})$, six precingular plates $\left(1^{\prime \prime}-6^{\prime \prime}\right)$, the canal plate $(\mathrm{X})$ and the ventral pore (vp). (D) Antapical view showing six postcingular plates $\left(1^{\prime \prime \prime}-6^{\prime \prime \prime}\right)$, two antapical plates $\left(1^{\prime \prime \prime \prime}, 2^{\prime \prime \prime \prime}\right)$ of unequal size and sulcal plates, with an anterior sulcal plate $(\mathrm{Sa})$, a median sulcal plate $(\mathrm{Sm})$, a right sulcal plate $(\mathrm{Sd})$, a left sulcal plate $(\mathrm{Ss})$, and a posterior sulcal plate $(\mathrm{Sp})$. The arrow in (D) denotes a group of pores present on the dorsal side of plate 2 "'".
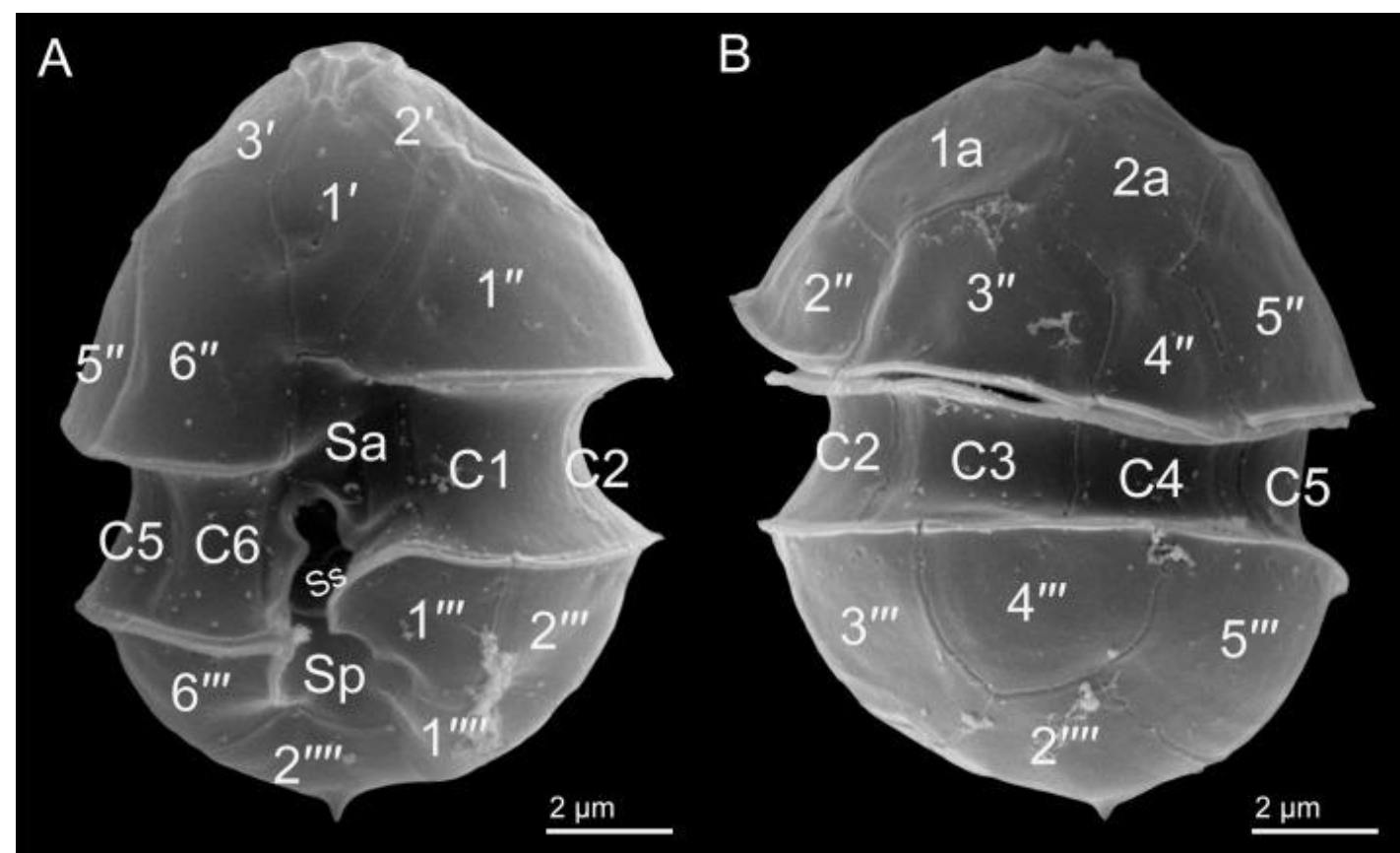

\section{C}

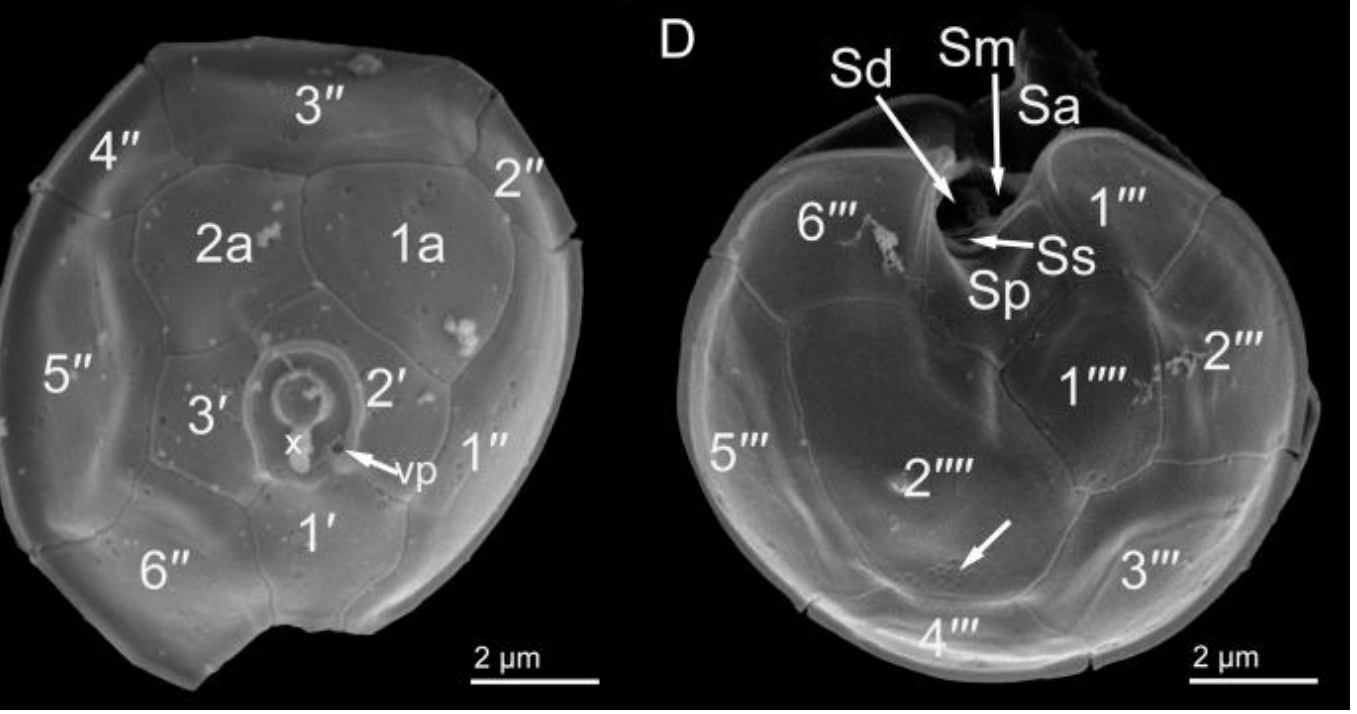


Fig. 7. Phylogeny of Azadinium and Amphidoma languida inferred from concatenated SSU, partial LSU rDNA and ITS sequences using Bayesian inference (BI). New sequences of Azadinium zhuanum, A. poporum and A. dalianense are indicated in bold. Branch lengths are drawn to scale, with the scale bar indicating the number of nucleotide substitutions per site. Numbers on branches are statistical support values to clusters on the right of them (left: Bayesian posterior probabilities; right: ML bootstrap support values). Black dots indicate maximal support ( $\mathrm{pp}=1.00$ in $\mathrm{BI}$ and bootstrap $=100 \%$ in ML respectively).

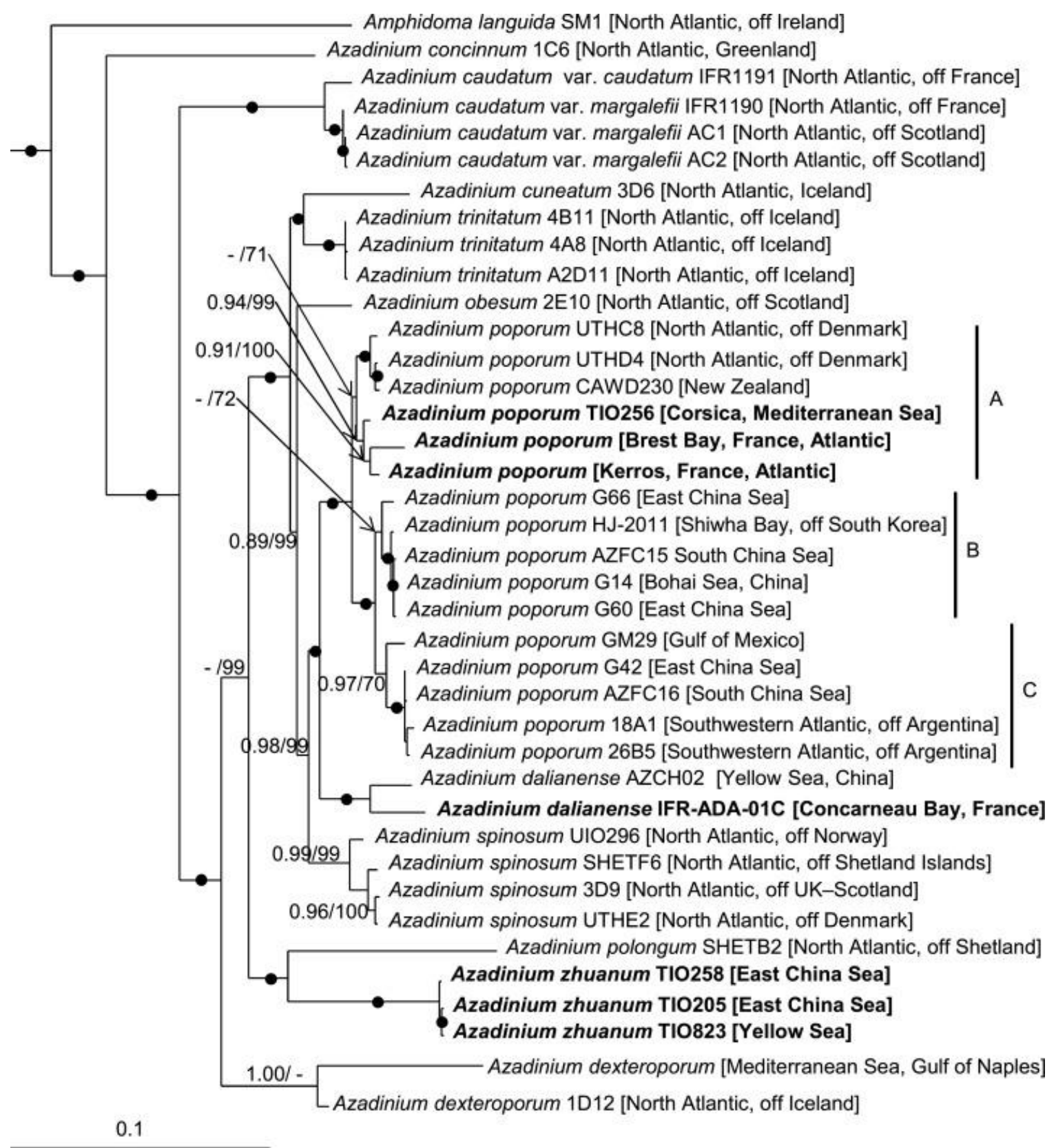


Fig. S1. A map showing the sampling stations where Azadinum zhuanum was encountered.

Fig. S2. Scanning electron microscopy of Azadinium zhuanum showing aberrant plate pattern. (A) Apical view showing three apical plates. (B) Apical view showing five apical plates. (C) Dorsal view showing one anterior intercalary plate. (D) Dorsal view showing three anterior intercalary plates. (E) Antapical view showing one antapical plate and 5 postcingular plates. (F) Ventral view showing three antapical plates.

Fig. S3. Phylogeny of Azadinium inferred from concatenated SSU, partial LSU rDNA and ITS sequences using Bayesian inference (BI). New sequences of Azadinium zhuanum, A. poporum and A. dalianense are indicated in bold. Branch lengths are drawn to scale, with the scale bar indicating the number of nucleotide substitutions per site. Numbers on branches are statistical support values to clusters on the right of them (left: Bayesian posterior probabilities; right: ML bootstrap support values). Black dots indicate maximal support ( $\mathrm{pp}=1.00$ in BI and bootstrap $=100 \%$ in ML respectively). 